\title{
Fannie Mae and Freddie Mac: Legal Implications of a Successor Cooperative
}

Michael E. Murphy

Follow this and additional works at: https://via.library.depaul.edu/bclj

\section{Recommended Citation}

Michael E. Murphy, Fannie Mae and Freddie Mac: Legal Implications of a Successor Cooperative, 10 DePaul Bus. \& Com. L.J. 171 (2012)

Available at: https://via.library.depaul.edu/bclj/vol10/iss2/3

This Article is brought to you for free and open access by the College of Law at Digital Commons@DePaul. It has been accepted for inclusion in DePaul Business and Commercial Law Journal by an authorized editor of Digital Commons@DePaul. For more information, please contact digitalservices@depaul.edu. 


\title{
Fannie Mae and Freddie Mac: Legal Implications of a Successor Cooperative
}

\author{
Michael E. Murphy*
}

Our task force members do agree on one high level concept, however: if some form of a GSE [Government Sponsored Entity] exists in the future, it should be established with a limited and specific charter that outlines a limited and specific mission, along with a strong regulator $\ldots{ }^{1}$

\section{INTRODUCTION}

The housing bubble has ironically revealed the fundamental flaws of Fannie Mae and Freddie Mac, while increasing our dependence on these failed institutions. Now under federal conservatorship and subsidized by the United States Treasury through periodic purchases of preferred stock, ${ }^{2}$ the two government-sponsored entities (commonly referred to as GSEs) accounted for of all mortgage-backed securities issued in $2010 . .^{3}$ Most other mortgage securities sold in the secondary market in 2010 were composed of FHA and VA guaranteed loans, making it nearly impossible for the middle class to buy a home without government approval. ${ }^{4}$ Meanwhile, the two GSEs are still struggling to regain profitability. The cumulative cost to the Treasury of preferred stock purchases needed to keep the GSEs solvent reached

* Judicial Attorney, California Court of Appeal, First District, 1987-2006; Ph.D. University of California, Berkeley; J.D. Stanford University; B.A. Harvard University; Lecturer, Geography Department, University of Texas at Austin, 1986-87; member of the California and Oregon Bar.

1. The Future of Housing Finance-A Review of Proposals to Address Market Structure and Transition: Hearing before the H. Comm. on Fin. Servs., 111th Cong. 60 (2010) [hereinafter Hearing] (statement of Kenneth E. Bentsen, Jr., Executive Vice President, Public Policy and Securities Industry and Financial Markets Association).

2. See Cong. Budget Office, CBO's Budgetary Treatment of Fannie Mae and FredDIE MAC 6, 8 (2010); FHFA Oversight: Current State of the Housing Government Sponsored Enterprises: Hearing before Subcomm. on Capital Mkts., Ins., and Gov't Sponsored Enters. of the H. Comm. on Fin. Servs. 111th Cong. 2 (2010) [hereinafter Hearing] (statement of Edward J. DeMarco, Acting FHFA Director).

3. Fed. Hous. Fin. Agency, Conservator's Report on the Enterprises' financial Performance, Fourth Quarter 2010, 5 (2010).

4. Id. at 5; See also Bethany McLean \& Joe Nocera, All the Devils Are Here: The Hidden History of the Financial Crisis 363 (2010). 
$\$ 154$ billion at the end of 2010 and is projected to rise somewhat higher. ${ }^{5}$ There is virtually no possibility of these funds being repaid. ${ }^{6}$

In April 2010, faced with insistent demands for action and few alternatives, the Obama administration solicited ideas from the financial community for how to deal with Fannie and Freddie. ${ }^{7}$ Some 570 comment letters revealed little consensus, and the official report of the inquiry ended vaguely with a sketch of three levels of possible federal intervention. ${ }^{8}$ Despite the lack of consensus amongst the comment letters, the authors shared many valuable insights. The letter from the Securities Industry and Financial Markets Association (SIFMA), for example, may have provided a touchstone for an eventual solution: it proposed a "high level concept"- the core functions of the GSEs, which serve a legitimate purpose, should be entrusted to an entity with a "limited and specific charter that outlines a limited and specific mission." SIFMA did not commit itself to a particular kind of chartered entity, but a later staff report from the New York Federal Reserve detailed an outline of a specific form of organization that satisfies this criterion. ${ }^{10}$ The GSE functions essential to support the secondary mortgage markets, it proposed, should be conducted by a cooperative owned and governed by participating banks.

At stake is the continued availability of the thirty-year, prepayable fixed-rate mortgage. ${ }^{11}$ Whatever its theoretical desirability may be, ${ }^{12}$ this American institution has entered deeply into social expectations

5. Fed. Hous. Fin. Agency, supra note 3 , at 17.

6. Viral V. Acharya et al., Guaranteed to Fail: Fannie Mae, Freddie Mac and the Debacle of Mortgage Finance 2-3 (2011). In addition, the Federal Reserve is saddled with $\$ 1.25$ trillion of mortgage-backed securities guaranteed by the two GSEs, which cannot be liquidated without disrupting financial markets. Id. at 91, 110-11.

7. Public Input on Reform of the Housing Finance System, 75 Fed. Reg. 21,146 to 47 (2010).

8. Dep't of the Treasury \& Dep't of Hous. \& Urban Dev., Reforming America's Housing Finance Markets: A Report to Congress (2011) [hereinafter Reforming Am.].

9. Hearing, supra note 1, at 10 (statement of Kenneth E. Bentsen, Jr.).

10. Toni Dechario et al., A Private Lender Cooperative Model for Residential Mortgage Finance, in The American Mortgage System: Crisis \& Reform 286 (Susan M. Wachter \& Marvin M. Smith eds., 2011) (Earlier released as Fed. Res. Bank of New York, Staff Report no. 466, August, 2010); see also The Present Condition and Future Status of Fannie Mae and Freddie Mac: Hearing before the Subcomm. on Capital Mkts., Ins., and Gov't Sponsored Enters. of the H. Comm. on Fin. Servs., 111th Cong. 159-62, (2009) [hereinafter Hearing] (statement of Bruce Morrison, Chairman of Morrison Public Affairs Group) (advocating a financial cooperative).

11. Andrew Davidson \& Anthony B. Sanders, Securitization After the Fall 5 (2009) ("Significantly, only the Government and GSE channels had the fully prepayble thirtyyear fixed rate mortgage as their primary product.").

12. Compare William M. Rohe et al., The Social Benefits and Costs of Homeownership: A Critical Assessment of the Research (Harv. Univ. Joint Center for Hous. Studies Low-Income Homeownership Working Paper Series, LIHO-01.12, 2001), available at http://www.jchs.harvard. edu/sites/jchs.harvard.edu/files/liho01-12.pdf, with Anthony Sanders \& Michael Lea, Do We Need the 30-Year Fixed Rate Mortgage? (Mercatus Ctr. of Geo. Mason Univ., Working Paper 
of two generations of Americans. First introduced by the FHA in 1948, it later featured in VA and private mortgage insurance and became the principal product of Fannie and Freddie in the mortgage securitization market. ${ }^{13}$ It not only offers a lower cost of home financing, but supports the goal of most families to have the option of continuing to live in the their home and neighborhood or, alternatively, to move when they wish. The thirty-year mortgage cannot be withdrawn without frustrating deeply embedded aspirations for homeownership and causing the housing market to slip into deeper crisis. ${ }^{14}$ A plausible economic justification also exists for a policy favoring the thirtyyear fixed rate mortgage. Because it offers monthly payments that "are both predictable and stable for the full life of the mortgage," the long-term fixed-rate mortgage is less prone to default than others ${ }^{15}$ and has less sensitivity to short term fluctuations in interest rate. It has been an element of relative stability in the housing market. ${ }^{16}$

The United States is nearly unique in its enjoyment of (or dependence on) the thirty-year, prepayable and self-amortizing, fixed-rate home mortgage. ${ }^{17}$ It survived undiminished during the revolution in home financing as lenders shifted from holding mortgage portfolios funded by customer deposits to a capital market system relying on securitization for funding and risk management. ${ }^{18}$ The long-term fixed-rate mortgage virtually disappeared from the portfolios of mortgage lenders after the savings and loan crisis of the late 1980s. By selling large bundles of long-term, fixed-rate mortgages on the capital market, lenders found a way to avoid being squeezed between low long-term mortgage yields and higher short-term interest rates, while

No. 11, 2011), available at http://mercatus.org/sites/default/files/publication/Do $\% 20 \mathrm{We} \% 20 \mathrm{Need}$ \%2030yr\%20FRM.Sanders.3.14.11.pdf.

13. See Richard K. Green \& Susan M. Wachter, The American Mortgage in Historical and International Context, 19 J. ECON. Persp. 93, 93-100 (2005); Davidson \& Sanders, supra note 11, at 9 fig.4.

14. Binyamin Appelbaum, New Housing Era: 30-year Mortgage May Fade, N.Y. Times, Mar. 4, 2011, at A1; Bethany McLean, Op-Ed., Who Wants a 30-Year Mortgage?, N. Y. Times, Jan. 5, 2011.

15. Ingrid Gould Ellen et al., The Secondary Market for Housing Finance in the United States: A Brief Overview, in The American Mortgage System: Crisis and Reform 7, 13 (Susan M. Wachter \& Marvin M. Smith eds., 2011).

16. Davidson \& Sanders, supra note 11, at 10-11; David Min, Future of Housing FI. nance Reform: Why the 30-Year Fixed-Rate Mortgage is an Essential Part of Our Housing FINANCE SYSTEM (2010), available at http://www.americanprogress.org/issues/2010/11/ pdf/housing_finance.pdf.

17. ACHARYA ET AL., supra note 6, at 119.

18. Green \& Wachter, supra note 13 , at 100. 
continuing to offer consumers the same thirty-year mortgages as before. ${ }^{19}$

The movement toward securitization, which began to gain force in the mid-1980s, generated a complicated series of innovations and shifting market structures, which has been well described elsewhere. ${ }^{20}$ The 2008 financial crisis, however, imposed a simplified pattern to the secondary mortgage market, perhaps indefinitely. The market is now dominated by three players and the traditional thirty-year fixed-rate mortgage. Ginnie Mae securitizes a resurgent market of mortgages insured by the Federal Housing Administration (FHA), Veterans Administration (VA), and Rural Home Service (RHS). Almost all are thirty-year fixed-rate mortgages. ${ }^{21}$ Ginnie's share of the secondary market rose from four percent in 2006 to twenty-six percent in 2010,22 about the same level as in the 1970 s. $^{23}$ As noted earlier, Fannie and Freddie now purchase about seventy percent of home mortgages. The thirty-year fixed-rate mortgage has been their standard product for securitization, typically accounting for about ninety percent of its business, though this share fell somewhat before the 2008 financial crisis. ${ }^{24}$ The once huge private securitization market almost vanished at the onset of the financial crisis. Speaking in May 2011, the director of the Federal Housing Finance Agency reported that "only two very small private-label securitizations of single-family loans have been done in the last 13 months." 25

The interface between Ginnie, Fannie, and Freddie and capital markets functions through the mediation of a little known but utterly vital

19. Id. at $98-99$.

20. Fin. Crisis Inquiry Comm'N, The Financial Crisis Inouiry Report (2011) [hereinafter FCIC], available at http:/www.gpoaccess.gov/fcic/fcic.pdf. See generally McLEAN \& Nocera, supra note 4; Gretchen Morgenson \& Joshua Rosner, Reckifess Endangerment: How Outsized Ambition, Greed, and Corruption Led to Economic Armageddon (2011); Gillian Tett, Fools Gold: How the Bold Dream of a Small Tribe at J.P. Morgan was Corrupted by Wall Street Greed and Unleashed a Catastrophe (2009).

21. DAVIDSON \& SANDERS, supra note 11 , at 9 fig.4.

22. Fed. Hous. Fin. Agency, supra note 3, at 5; James B. Lockhart III, Director, Fed. Hous. Fin. Agency, Speech at the American Securitization Forum (Feb. 9, 2009) available at www. fhfa.gov/webfiles/823/ASFSpeech2909.pdf.

23. Green \& Wachter, supra note 13 , at 97.

24. See Davidson \& SANDERs, supra note 11, at 9; The Impact on Homebuyers and the Housing Market of a Conforming Loan Limit Increase: Hearing before the H. Comm. on Fin. Servs., 110th Cong. 57 (2008) [hereinafter Hearing] (statement of Thomas Hamilton, Managing Director, Barclays Capital).

25. Transparency as an Alternative to Risk Retention, Before the Subcomm. on TARP, Fin. Servs. \& Bailouts of Public \& Private Programs of the H. Comm. on Oversight and Gov't Reform, 112th Cong. 2 (2011) (statement of Edward J. DeMarco, Acting Director of Federal Housing Finance Agency) available at http://www.gpo.gov/fdsys/pkg/CHRG-112hhrg68217/pdf/ CHRG-112hhrg68217.pdf. 
institution-the "to-be-announced" (TBA) secondary market. This extraordinary system of financial engineering succeeds in converting an immense number of small, highly diverse home mortgages into a fungible product that is sold to investors worldwide in large lots, like shipments of soybeans. ${ }^{26}$ When private securitization collapsed in the housing crisis, ${ }^{27}$ the TBA market maintained a relatively stable level of active trading. ${ }^{28}$ The TBA market is now unquestionably the fulcrum of the system of housing finance. As Davidson and Sanders note, "[I]t serves as an extremely efficient way to distribute hundreds of billions of new origination in MBS [mortgage-backed securities] each year."29 Its demise would threaten to reduce the thirty-year fixed rate mortgage to a niche product confined largely to government insurance programs. ${ }^{30}$

The GSE cooperative proposed by the New York Federal Reserve staff report would assume most of the securitization activities of Fannie and Freddie in the TBA secondary market. It would thereby seek to preserve the core GSE business that continues to work well. Other GSE activities, however, would be gradually wound down or transferred to other agencies. The institutions' massive holding of mortgage securities would presumably be transferred to a kind of receivership and their portfolio of multifamily mortgages shifted to a government agency. Though the proposed cooperative would provide no more than the institutional context for one element of a broader plan, it could be the element that allows the other parts to fit.

There is no novelty to the idea of a financial cooperative. The Federal Home Loan Bank System (FHLBank System), with about $\$ 1$ trillion in assets, and the Farm Credit Service are both controlled by banks participating in their financial services. The FHLBank System has existed since 1932; the Farm Credit Service since 1916. During the first nineteen years of its existence, Freddie Mac was an agency of the FHLBank System and under cooperative control. ${ }^{31}$ Several finan-

26. See James Vickery \& Joshua Wright, TBA Trading and Liquidity in the Agency MBS Mar$k e t$, in Fed. Res. BANK. OF New York (Staff Reports, no. 468, 2010).

27. Id. at 1 ("Mortgage securitization by private financial institutions has declined to negligible levels since the onset of the financial crisis in mid-2007.").

28. Id. at 1, 4; DAvidSON \& SANDERS, supra note 11 , at 6 ("a robust and stable market"); Hamilton, supra note 24 , at 4 ("These markets have remained stable.").

29. DavidSON \& SANDERS, supra note 11 , at 6.

30. Id. at 5 ("Without such a market the risks of originating and securitizing fixed rate mortgages would likely exceed the profits from origination."); Hearing, supra note 1, at 56 ("It is notable that no other mortgage market or funding system via depositories has ever provided sustained liquidity to the extent that the GSE MBS markets have.") (statement of Kenneth E. Bentsen, Jr.).

31. See infra Part VI. 
cial consortiums, though not actually organized on a cooperative basis, still resemble cooperatives in that they provide services to the financial services industry under the common ownership of a number of banking institutions. ${ }^{32}$ The current literature on reform of the housing GSE, appearing in academic studies, ${ }^{33}$ policy statements of professional organizations, ${ }^{34}$ and congressional correspondence and testimony, ${ }^{35}$ frequently mentions creation of an industry cooperative among the menu of options-usually with a brief gloss lacking detailed discussion.

These frequent, but summary, references to the option of a cooperative successor to the GSEs have left a trail of unexamined assumptions. It is most notable that the objections to a securitization cooperative consistently relate to perceived problems inherent in cooperative organization. ${ }^{36}$ This article aims to examine these essentially legal issues. It will reveal one serious dilemma arising from the

32. E.g., CLS Bank, Depository Trust \& Clearing Corporation, ICE Trust. See Dechario et al., supra note 10.

33. See, e.g., Acharya Et al., supra note 6, at 157-158; Davidson \& SANDERs, supra note 11, at 23; Ingrid Gould Ellen \& Mark A. Willis, Improving U.S. Housing Finance Through Reform of Fannie Mae and Freddie Mac: A Framework for Evaluating Alternatives, in THE AMERICan Mortgage System: Crisis \& Reform 323-24 (Susan M. Wachter \& Marvin M. Smith eds., 2011); Adam J. Levitin \& Susan M. Wachter, Information Failures and the U.S. Mortgage Crisis, in The American Mortgage System, supra; Robert Van Order, Some Thoughts on What to Do with Fannie Mae and Freddie Mac, in The American Mortgage System, supra; David Reiss, Fannie Mae, Freddie Mac, and the Future of Federal Housing Finance Policy: $A$ Study of Regulatory Privilege, 61 ALA. L. Rev. 907, 951-52 (2010); Thomas H. Stanton, The Failure of Fannie Mae and Freddie Mac and the Future of Government Support for the Housing Finance System, 18 J. L. \& PoL'y 217, 242-243 (2009); Richard K. Green \& Ann B. Schnare, The Rise and Fall of Fannie Mae and Freddie Mac: Lessons Learned and Options for Reform, 9-10 (Nov. 19, 2009) (unpublished paper) (on file with the University of California Lusk Center for Real Estate), available at http://www.usc.edu/schools/price/lusk/research/pdf/wp_2009-1001.pdf; Susan Woodward \& Robert Hall, What To Do About Fannie Mae and Freddie Mac?, FIn. CRIsIs \& RECESSION Blog (Jan. 28, 2009), http://woodwardhall.wordpress.com/2009/01/28/what-to-doabout-fannie-mae-and-freddie-mac/.

34. See Hearing, supra note 10, at 47 (statement of Bruce Morrison); Mortg. Bankers Ass'N Council on Ensuring Mortg. Liquidity, Key Considerations for the Future of the Secondary Mortgage Market and the Government Sponsored Enterprises (GSEs) (2009), available at http://www.mbaa.org/files/ResourceCenter/GSE/KeyConsiderationsforthe FutureoftheSecondaryMarketandGSEs.pdf.

35. See The Future of Housing Finance-A Review of Proposals to Address Market Structure and Transition: Hearing Before the H. Comm. on Fin. Servs., 111th Cong. 166, 170 (2010) [hereinafter Hearing] (statement of Philip L. Swagel \& Susan M. Wachter); Fannie Mae and Freddie Mac: Analysis of Options for Revising the Housing Enterprises' Long-term Structures: Hearing Before the S. Comm. on Banking, Hous. and Urban Affairs, 111th Cong., 7-8 (2009) (statement of William B. Shear, Director Financial Markets and Community Investment); Morrison, supra note 10; N. Eric Weiss, Cong. Research Serv., R40800, Options to Restructure Fannie MaE ANd Freddie MaC 15 (2009).

36. This emphasis is especially evident in the GAO's contribution to the debate. See Letter from William B. Shear, Director, Fin. Mkts. and Cmty. Inv., to Congressional Committees (Nov. 
fact that five institutions now account for about sixty percent of all mortgage originations in $2009 .{ }^{37}$ Other perceived problems turn out to be either nonexistent or amenable to familiar means of mitigation. It does not necessarily follow that a securitization cooperative is the only sound public choice; it may be possible to devise some other accountable institution with a "limited and specific" charter to provide needed functions. The objective here is simply to add clarity to discussion of the cooperative option for GSE reform.

As general background, Part II presents a brief description of the TBA secondary mortgage market and explains the critical importance of standardization and a uniform system of credit enhancement. These considerations dictate the functions to be conferred on a securitization cooperative. Part III reviews the problems involved in formation and capitalization of the proposed cooperative and advocates a federal charter for a conventional Subchapter T cooperative. Part IV examines questions regarding corporate governance of cooperatives. After dismissing a perplexing series of misconceptions found in the literature of GSE reform, it sketches the general features of corporate governance that may be expected for the proposed cooperative and discusses means of preventing its domination by large mortgage originators. Part V addresses a series of secondary issues implicit in the foregoing discussion - fiduciary duties, economies, and too-big-to-fail concerns. Lastly, Part VI discusses inferences drawn by certain critics from the mixed record of the FHLBank System and the Farm Credit System.

\section{The TBA Secondary Market}

The focus of this Article does not extend to the financial structure of the mortgage market, but a brief sketch of the TBA secondary market is necessary to describe the mission of the proposed securitization cooperative and to make the point that this mission can be carried out by a cooperative with a "limited and specific charter."

The primary product currently traded in the TBA secondary mortgage market is the pass-through mortgage-backed bond. ${ }^{38}$ The three issuers in this market-Fannie, Freddie, and Ginnie-purchase individual mortgages from lenders, assemble them into pools, and sell bonds to investors that carry the right to payments of interest and

15, 2010) [hereinafter Shear Letter] (on file with U.S. Gov't Accountability Office, GAO-1133R), available at http://www.gao.gov/new.items/d1133r.pdf.

37. Id. at 36 (sixty-two percent as of year-end 2009).

38. For a description of collateralized mortgage obligations and other securities also traded in the secondary market, see Hamilton, supra note 24 , at 8 . 
principal in the given pools of mortgages. The unique feature of the TBA market is that it allows the issuers to contract to deliver a collection of mortgages at a future date without identifying the actual mortgages at the time they enter into the contract with investors. At the time of bond purchase, the mortgages may then not exist. The contract specifies only six parameters: the issuer, maturity, coupon, par amount, settlement date, and price. The settlement date, when pools of mortgages are exchanged for cash, is usually thirty to ninety days after the contract date. Distinct settlement dates are scheduled for mortgages that fall into particular product types, such as thirty-year Freddie Mac mortgages. Two days before the settlement date, the issuer identifies the actual collections of mortgages in pools that will be delivered to satisfy the terms of the contract. In selecting mortgages for delivery, the issuer follows the principle of choosing first those with the least desirable characteristics. The application of this "cheapest-to-deliver" principle is factored into the contract price. ${ }^{39}$

The TBA market is able to engage in this "forward" trading because the three participating issuers enjoy an exemption in the Securities Act of 1933. A contract to deliver unidentified mortgages at a future date would otherwise violate securities law disclosure requirements. This privilege to sell mortgages that have not yet been originated, or aggregated into pools, has important benefits for banks and investors. It effectively offers banks the ability to hedge interest rate fluctuations while offering borrowers a fixed-rate good for thirty to ninety days. ${ }^{40}$ As Vickery and Wright explain, "[W]ithout TBAs, originators would have to engage in sophisticated trading strategies using a variety of derivatives to replicate the effect of a TBA." 41 This would involve additional costs and would especially handicap smaller banks with limited capacity to engage in derivative trading. The banks, moreover, are relieved of the need to "warehouse" loans for a period before selling them on the secondary market, thereby reducing transaction costs and taking the loans off their balance sheets. For investors, the ability to contract to purchase mortgages in advance of the trade date offers an opportunity to sell the contract before that date and invest the proceeds in another contract further in the future. This option is especially valuable to smaller investors who may face

39. The best description of the TBA secondary market is found in Vickery \& Wright, supra note 26. See also Dechario et al., supra note 10, at 289-293; DAvidson \& SANDERs, supra note 11; Hamilton, supra note 24.

40. See Ellen et al., supra note 15 , at 9-10.

41. Vickery \& Wright, supra note 26 , at 14. 
operational difficulties in funding the purchase of bonds, which are generally traded in very large lots. ${ }^{42}$

The process of aggregating mortgages into pools according to the "cheapest-to-deliver" principle effectively eliminates concerns about geographical diversity of the mortgages and helps transform the mortgages into a homogeneous product. To be eligible for TBA trading, moreover, the mortgages must meet well known standards of size, credit quality, documentation, and processing that are imposed by two gate-keepers - the three issuers themselves and SIFMA, the professional organization that carries out the trading operations. Fannie and Freddie require participating mortgage lenders to employ certain standardized documents, underwriting procedures, and servicing practices. $^{43}$ For its part, SIFMA regulates trading according to uniform standards and procedures contained in a very detailed manual, the "Uniform Practices for Clearance and Settlement of MortgageBacked Securities." 44 SIFMA may refuse to trade pools that do not meet its standards of homogeneity. ${ }^{45}$

The process of pooling and standardization contributes to the creation of a homogeneous and fungible product, ${ }^{46}$ but by far the most important source of fungibility is the credit guarantee that the three issuers extend to all securities backed by mortgages within their pools. By assuring investors that they will receive a stipulated cash flow of principal interest from the underlying mortgages, the guarantee shifts the credit risk from the huge pools of small mortgages to the credit of the issuers themselves. Without the credit guarantee, the secondary mortgage market would not be able to provide continued liquidity to

42. Id. at 13-14.

43. Andrea J. Boyack, Laudable Goals and Unintended Consequences: The Role and Control of Fannie Mae and Freddie Mac, 60 AM. U. L. REv. 1489, 1500-01; Julia Patterson Forrester, Fannie Mae/Freddie Mac Uniform Mortgage Instruments: The Forgotten Benefit to Homeowners, 72 Mo. L. Rev. 1077 (2007); Adam J. Levitin \& Susan M. Wachter, Explaining the Housing Bubble 76-79 (Georgetown Bus., Econ. and Regulatory Law Research Paper No. 10-16, 2010), available at http://ssrn.com/abstract $=1669401$.

44. See Vickery \& Wright, supra note 26 , at 8.

45. See Hamilton, supra note 24 , at 14-20.

46. The invaluable quality of homogeneity allows the TBA secondary market to avoid the transaction costs of dividing securities into classes, or tranches, according risk characteristics. See Green \& Wachter, supra note 13, at 109-10. But the TBA market also offers issuers the flexibility of marketing tailor-made products in a "specified pool" market. See Hearing, supra note 24, at 13 (written testimony of Thomas Hamilton). The decision to use this non-liquid market is one of many discretionary options in the process of securitization. The formation of securitization cooperation might cause this much smaller "specified pool" market to contract further if the cooperative was chartered to deal only in a few traditional mortgage products. 
home financing and the housing slump would immeasurably worsen. ${ }^{47}$ It is true that private securitization, though lacking a comparable credit guarantee, enjoyed a decade of growth in the 1990s and a shortlived domination of the market during 2003 to $2007,{ }^{48}$ but this success was stimulated by factors that abruptly disappeared in the financial crisis-spurious AAA ratings by bond rating agencies, lax regulation, and the use of credit default swaps to support exotic financial instruments. ${ }^{49}$ While it remains a possibility that private channels of securitization may revive in some segments of the market, caution born of experience will likely temper future investing. Until significant private securitization returns, the TBA market, which offers a secure credit guarantee for all products, will remain virtually the only functioning means for mortgage lenders to access the secondary mortgage market. 50

As a government agency, Ginnie Mae offers an explicit guarantee, backed by the full faith and credit of the federal government, on securities backed by mortgages that are independently insured by other government agencies. Until September 2008, the guarantees of Fannie Mae and Freddie Mac relied on a perceived federal government guarantee. The bonds themselves explicitly disclaimed any federal government sponsorship ${ }^{51}$ and the guarantee fees were modest, ${ }^{52}$ but investors inferred that the federal government was actually on the hook because of the privileged nature of the GSEs, the federal government's involvement in their activities, and their sheer size. ${ }^{53}$ The financial crisis proved that they were right. After being placed in government conservatorship, the GSEs have enjoyed a de facto federal guarantee. Preferred stock agreements between the GSEs and the Treasury commit the federal government to keep the GSEs solvent through 2012. The Treasury and Federal Reserve further demon-

47. ACHARYA ET AL., supra note 6, at 143-44; Eric S. Belsky \& Nela Richardson, Understanding the Boom \& Bust in Nonprime Mortgage Lending 130 (Joint Ctr. for Hous. Studies, Harvard Univ., 2010); Ellen \& Willis, supra note 33, at 307-09.

48. Lockhart, supra note 22, at 2; ACHARYA ET AL., supra note 6, at 42; Hearing, supra note 1, at 54 (statement of Kenneth E. Bentsen, Jr.).

49. See Boyack, supra note 43, at 1522-23; Patricia A. McCoy et al., Systemic Risk Through Securitization: The Result of Deregulation and Regulatory Failure, 41 ConN. L. Rev. 1327, 1327-75 (2009).

50. See Belsky \& Richardson, supra note 47, at 86; Hearing, supra note 24 (written testimony of Thomas Hamilton), at 6; Van Order, supra note 33, at 11-12.

51. Federal Housing Enterprises Financial Safety and Soundness Act, 12 U.S.C. $\$ 4501$ et seq. (1992).

52. Fed. Hous. Fin. Agency, supra note 3, at 11; The Present Condition and Future Status of Fannie Mae and Freddie Mac, Hearing before the H. Subcomm. on Capital Mkts., Ins., and Gov't Sponsored Enters. of the H. Comm. on Fin. Servs., 111th Cong., 27 (2009).

53. See Ellen et al., supra note 15 , at 9 ; Green \& Wachter, supra note 13, at 111. 
strated their commitment to honor GSE obligations by their massive purchases of the GSE obligations and securities. ${ }^{54}$ But when the preferred stock agreement runs out at the end of 2012, the GSEs will face crossroads. The old implicit federal guarantee, of course, will never return. The choice is between no guarantee, with the consequent dramatic contraction of liquidity in the secondary mortgage market, ${ }^{55}$ or a newly designed explicit guarantee administered by a reformed institution.

The private insurance industry cannot supply a credit guarantee adequate to support the existing level of liquidity in the secondary mortgage market, though it can play a supplementary role. ${ }^{56}$ Before the 2008 financial crisis, eighty-five percent of this industry's business, largely consisting of six companies, consisted in providing credit enhancement for mortgages with high loan-to-value ratios so that the mortgages would qualify for securitization by Fannie and Freddie. ${ }^{57}$ In 2007, these six companies lost an average of sixty percent of their stock market valuation. ${ }^{58}$ As rising defaults caused the GSEs to be placed in conservatorship, the same problems eroded the insurers' capital positions and caused their credit ratings to fall. The companies tightened underwriting standards, ceased issuing new insurance, and even deferred payment of claims on existing policies. ${ }^{59}$ In 2008, the private industry's share of mortgage insurance fell to less than half of government insurance programs. ${ }^{60}$ New business fell sixty-five percent in the first quarter of 2009 from the previous first quarter. ${ }^{61}$ When one considers the size of the housing sector in the economy (more than one-fifth of GDP) ${ }^{62}$ and the amount of outstanding mortgage debt of the two GSEs ( $\$ 3.5$ trillion), ${ }^{63}$ it becomes clear that the private mortgage insurance industry is far too small and much too weak to offer credit guarantees that will satisfy the concerns of investors in global capital markets.

\footnotetext{
54. See Cong. Budget Office, Fannie Mae, Freddie Mac, and the Federal Role in the Secondary Mortgage Market 9-10 (2010).

55. See Boyack, supra note 43 , at 1540 nn.231-33.

56. ACHARYA ET AL., supra note 6, at 150-51.

57. The Present Condition and Future Status of Fannie Mae and Freddie Mac: Hearing Before the Subcomm. on Capital Mkts, Ins., and Gov't Sponsored Enters., 111 Cong. 144 (2009) [hereinafter Hearing] (statement of James B. Lockhart III).

58. ACHARYA ET AL., supra note 6, at 151.

59. Hearing, supra note 1, at 9 (statement of Kenneth E. Bentsen, Jr.).

60. Fed. Hous. Fin. AgenCy, supra note 3, at 2.

61. Hearing, supra note 57, at 144 (statement of James B. Lockhart III).

62. Eric Belsky \& Joel Prakken, Housing Wealth Effects: Housing's Impact on Wealth Accumulation, Wealth Distribution and Consumer Spending 1 (Joint Ctr. For Hous. Studies Harvard U. 2004).
}

63. ACHARYA ET AL, supra note 6 , at 5 . 
The task of maintaining the current liquidity of the secondary home mortgage market, if that is regarded as a priority, requires some sort of government intervention, probably in the form of reinsurance, which would provide a solid backstop for private mortgage insurance and the issuers' own self-insurance programs. The staff report of the New York Federal Reserve proposed a detailed scheme that would insure that the burden of mortgage defaults would fall first on the borrower by enforcing minimum down payment requirements; next on the cooperative by charging losses to a mutualized reserve divided into vintages according to the year in which the mortgages were guaranteed; and lastly on a government agency providing a kind of reinsurance. By charging losses to particular vintages, the burden of losses would be borne proportionately by lenders participating in those years without affecting reserves held for ongoing operations. The trigger for reinsurance payments would consist of the depletion of reserves for a particular vintage, and the payments would be made only to that vintage. The reserve might, at the cooperative's option, be bolstered by purchase of private mortgage insurance. ${ }^{64}$ The staff report represents a sophisticated and detailed variation on a number of other similar proposals. ${ }^{65}$

\section{The Charter}

As a successor to the GSEs, a securitization cooperative would have responsibility (a) to maintain the existing system of securitization in the TBA market and (b) to operate a restructured scheme of explicit and funded credit guarantees, backed by a federal agency offering reinsurance protection. Both activities are complex, highly technical, and would involve a critical degree of discretion, but they could provide a "limited and specific mission" for the cooperative. The objective would be to preserve the liquidity and other financial benefits of the TBA secondary market. Its success would be measured by the extent that it preserved the widespread availability of the prepayable and self-amortizing, fixed-rate thirty-year mortgage, and other familiar financial products offering comparable social and economic benefits.

The idea of such a "limited and specific charter" raises three threshold questions: First, where would it be chartered? Second, how would

64. See Dechario et al., supra note 10 , at 294-98.

65. See, e.g., Hearing, supra note 10, at 40, 162 (statement of Bruce Morrison); ACHARYA ET AL., supra note 6, at 153-58; Hearing, supra note 1, at 9-10, 13 (statement of Kenneth E. Bentsen, Jr.); Davidson \& SANDERS, supra note 11 , at 16. 
it be capitalized? And third, would it succeed in attracting and keeping membership?

In considering the place of chartering, one encounters the patchwork development of cooperative law that contrasts with the evolution of corporate law. Corporations early evolved the concept of incorporation for general business purposes ${ }^{66}$ which allowed the corporation to engage in any activity or to adopt any form of organization adapted to that activity, unless constrained by particular legislative enactments. In contrast, the statutory law of cooperatives has spawned an array of specifically authorized cooperatives, such as those organized for agricultural marketing, rural electrical service, depository financial institutions, insurance, and housing - ${ }^{67}$ none of which is remotely suitable for the contemplated securitization cooperative. A few states have adopted a general cooperatives law, but without exception, these laws are replete with unnecessary and inappropriate provisions. ${ }^{68}$ It would still be possible to incorporate the securitization cooperative under the general law of a particular state, such as Delaware, and adopt bylaws establishing a cooperative organization. ${ }^{69}$ But since the state-chartered cooperative will be subjected to extensive federal regulation, the result would be a hybrid state-federal creation that might generate uncertainty and disputes. The preferable alternative appears to be to secure a specific legislative authorization for the federal chartering of the cooperative, following the precedents of national banks, federal thrifts, and credit unions. ${ }^{70}$ As described earlier, federal legislation is required in any event for the reinsurance function.

The securitization cooperative, however, can fit into the established parameters of a Subchapter $\mathrm{T}$ cooperative. The chapter includes a catchall provision that refers generally to a "corporation operating on a cooperative basis." 71 This phrase, left undefined in the Revenue Code, has gained a concrete meaning through judicial interpretation. By fitting into this established mold, the securitization cooperative would not only secure the clarity in tax treatment but would avoid the

66. See Thomas Conyngton, The Modern Corporation: Its Mechanisms, Methods, Formation ANd Management 19 (4th ed. 1910).

67. See Charles T. Autry \& Roland F. Hall, The Law of Cooperatives $37,42-49$ (12th ed. 2009).

68. See, e.g., Nev. Rev. Stat. $\$ \$ 81.170-81.270$ (2010); N.Y. Coop. Corp. Law (Consol. 2011); Or. Rev. Stat. §§ 62.005-62.455 (2010); Wis. STAt. $\S 185.01-185.985$ (2010).

69. See Autry \& Hall, supra note 67 , at 37.

70. 12 U.S.C. $\$ \S 21-78$ (2006) (national banks); 12 U.S.C. $\S 1464$ (2006) (federal thrifts); 12 U.S.C. $\S 1754$ (2006) (federal credit unions).

71. I.R.C. $\S \S 1381-88(2006)$. 
privileged legal status for which the GSEs have been justly criticized. Tax qualification under Subchapter T would also impose on the cooperative a kind of discipline by encouraging it to stay within its original charter. Income generated from business unrelated to its cooperative organization would incur double taxation when received by the cooperative and when received by members upon distribution. ${ }^{72}$

The judicial interpretation of Subchapter $\mathrm{T}$ comports with an ordinary understanding of a cooperative business. The seminal decision, Puget Sound Plywood, Inc. v. Commissioner, ${ }^{73}$ recognizes three factors defining cooperative organization. The first factor, "subordination of capital," means that the cooperative is operated for the pecuniary benefit of members. Outside investors, if any, gain no control over the management of the cooperative. The second factor is "democratic control" by the members themselves. The third and most fundamental factor is that "the excess of operating revenue over the costs incurred in generating those revenues is distributed to members in proportion to their participation in the cooperative."74

These flexible and reasonable criteria drawn from earlier jurisprudence of cooperative enterprises can stand as the guidelines for the cooperative organizations of the proposed cooperative. The requirement of democratic control, however, presents issues beyond the purview of the Puget Sound court. The members of the cooperative at issue there gathered in meetings where each had a single vote. The concept of democratic control is surely not confined to this simple situation, but there is a paucity of precedents on how far it can be extended..$^{75}$ Thus, it would be prudent to secure a revenue ruling to make clear that Subchapter $\mathrm{T}$ allows the securitization cooperative to adopt contemporary standards of good corporate governance applicable to financial institutions. ${ }^{76}$

Though a securitization cooperative would be one of a kind, we may approach the issues involved in its capitalization by briefly considering the case of a generic Subchapter T cooperative. ${ }^{77}$ Cooperatives uni-

72. See Autry \& Hall, supra note 67, at 34; See generally Carla Neeley Freitag, TaXAtion of CoOperatives and their Patrons (2007).

73. 44 T.C. 305 (1965).

74. See Autry \& Hall, supra note 67 , at 88.

75. See, e.g., Thwaites Terrace House Owner Corp. v. Comm'r, 72 T.C.M. 578, 581 (1996) ("[T]he fact that petitioner's shareholders have one vote for each share they own ... and that they own shares based on the relative sizes of their various dwelling units is not contrary to democratic principles."). See also N.Y. Coop. Corp. Law \$ 46 (Consol. 1967) (New York cooperative law similarly allows proportional voting rights based on the patronage of members).

76. See infra Part IV.

77. See Autry \& Hall, supra note 67. See also Kimberley A. Zeuli \& Robert Cropp, Cooperatives: Principles and Practices in the 21st Century (4th ed. 2004), available at 
formly require prospective members to make some minimum capital contribution as a price for membership; this may take the form of a mandatory purchase of capital stock or simply purchase of a membership certificate. ${ }^{78}$ To the extent that the cooperative desires to encourage widespread membership, it will need to keep the price of membership low. A starting cooperative may seek additional capital by issuing preferred stock or capital certificates providing essentially the same rights as preferred stock. Once established, a cooperative is able look to members for ongoing capital needs and in fact must do so since cooperatives are not structured as investment opportunities for third parties. A well managed cooperative sets its pricing so that it will retain some net earnings (termed net margins in the cooperative world) to provide for business contingencies. The net margin is annually returned to members in proportion to their participation as patronage refunds. However, the cooperative retains a portion of the patronage refunds (commonly termed a retained capital credit) as equity capital, which is ordinarily allocated to members' capital accounts, though a portion can be assigned to the permanent capital of the cooperative. ${ }^{79}$ The accumulation of capital in individual accounts would over time tend to cause the capitalization of the cooperative to diverge from current patterns of patronage. Thus, the allocated capital accounts are ordinarily returned to members after a period of years through a payment program (commonly called equity redemption). ${ }^{80}$

A securitization cooperative would inevitably follow these general outlines. The right to secure capital by withholdings from members would serve as a source of financial strength, but it comes with an implied obligation to return funds in individual capital accounts over time, thus creating a kind of revolving fund. The management of the cooperative can adjust net margins and patronage refunds year by year to meet the changing capital needs of the cooperative..$^{81}$

As Davidson and Sanders observe, "Cooperatives ... benefit when outside capital is not available or desirable." 82 With the GSEs in conservatorship and still losing money, and the housing market facing un-

http://learningstore.uwex.edu/assets/pdfs/A1457.pdf. See, e.g., U.S.D.A., CoOPERATIVE FINANCING AND TAXATION (1995), available at http://www.rurdev.usda.gov/rbs/pub/cir1sec9.pdf.

78. See Autry \& HALL, supra note 67, at 71-74 (discussing the distinction between stock and non-stock cooperatives).

79. On the rules regarding qualified patronage refunds, which are deductible by the cooperative and taxable to members, and nonqualified refunds with converse tax treatment, see AUTRY \& HALL, supra note 67, at 81; FreITAG, supra note 72, at Part IV(B).

80. AuTRY \& Hall supra note 67 , at 82-85.

81. Id. at 80 .

82. Davidson \& SANDERS, supra note 11 , at 15. 
certain prospects, a cooperative offers an attractive alternative since it provides a means of securing capital investment through revenues generated by members using its services. The cooperative's ability to draw on members will give cooperatives an advantage over other kinds of business organizations in the event of "disruptions to the capital markets," 83 such as an "extreme housing crisis." 84 Cooperatives retain financial resources when money is scarce.

The initial capital needs of the cooperative present a distinct problem since they cannot be supplied by a system of retained capital credits in place after the cooperative is in business. As a financial intermediary, a securitization cooperative would have relatively modest capital needs-its primary activity after all involves a service-but it would still need some initial funding in the form of cash reserves and short-term obligations. The business of buying and securitizing home mortgages entails a certain gap between purchase and sale and the capacity to seize opportunities for large purchases when they arrive. Fannie and Freddie have both maintained substantial non-mortgage investments to handle such cash management and liquidity needs. ${ }^{85}$ This initial capital barrier, though relatively small, still requires careful planning. Many members may be unwilling to purchase an offering of preferred stock or capital certificates; and if only some members make such an investment, it might set the stage for future divisions. Accordingly, it seems worth considering the option of a program of government-sponsored seed money, such as that which Fannie Mae and Freddie Mac enjoyed in their inception. ${ }^{86}$

Some commentators have raised the possibility that the securitization cooperative would be crowded out by private competition ${ }^{87}$ or that it would lead to multiple cooperatives, fragmenting the housing finance system. ${ }^{88}$ Both scenarios are almost inconceivable if the successor to the GSEs should succeed in offering mortgage lenders the same access to capital that they now enjoy in the TBA secondary mar-

83. Id.

84. AChARYA Et AL., supra note 6, at 158.

85. See U.S. Gov't AcCountability Office, GAO/GGD-98-48, Government-Sponsored Enterprises: Federal Oversight Needed for Nonmortgage Investments (1998) [hereinafter Fed. Oversight Report] (report to the Chairman, H. Comm. on Banking and Fin.).

86. See Housing Act of 1934, Pub. L. No. 73-479, $\S 303,48$ Stat. 1246 (codified at 12 U.S.C. $\S 1701$ et seq. (2006)) (indicating the purchase of Fannie Mae's preferred stock by Secretary of the Treasury); Emergency Home Finance Act of 1970, Pub. L. No. 91-351, § 304, 84 Stat. 454 (codified as amended at 12 U.S.C. $\$ \S 1451-59$ (2006)) (indicating the mandatory purchase of common stock by Federal Home Loan Banks).

87. See Hearing, supra note 35, at 173-74 (testimony of Philip L. Swagel \& Susan M. Wachter).

88. See Shear Letter, supra note 36 , at 35. 
ket. The extraordinary size and liquidity of this market, if undiminished, would exert a virtually irresistible magnetic force attracting and keeping members. But as we have seen, the support of the TBA market depends on many factors, especially a credible system of credit guarantees. Any successor to the GSEs-and the TBA market itself-would indeed falter if an adequate credit guarantee program were not put in place. If a securitization cooperative should suffer this fate, the fault would not lie in its cooperative organization, but on the financial structure of the system of credit guarantees.

\section{Governance Structure}

One of the most perplexing assumptions to appear in discussions of GSE reform is that the cooperative option would be burdened by inefficient modes of collective decision making. Green and Schnare cite "problems associated with the governance structure of a cooperative" 89 as they explain how "[m]ultiple stakeholders can prevent timely and effective decision-making, and limit the entity's ability to respond to market forces." 90 Similarly, the GAO analyst, Shear, reports that

some observers believe that cooperatives can take an extended period to achieve consensus on key business issues as compared with individual companies because all members are involved in making the final decisions. As a result, some question whether the cooperative model and any associated delay in decision making would be well suited for complex and dynamic secondary mortgage market functions. ${ }^{91}$

These observations are apparently drawn from perceived limitations of small agricultural and workers' cooperatives, but the proposed securitization cooperative would not look to rural communities for models of its corporate governance structure. ${ }^{92}$ As a federally chartered corporation, it would be free to adopt the best practices of corporate America and would surely begin with consideration of such respected repositories of good corporate governance practices such as the American Law Institute, The Business Roundtable, and The Conference Board. These sources generally call for a board of moderate

\footnotetext{
89. Green \& Schnare, supra note 33 , at 10.

90. Id.

91. See Shear Letter, supra note 36, at 35.

92. The only sources on cooperative organization cited by the GAO analyst, William Shear, are in fact addressed to rural communities. Id. at 23. See generally Brian M. HeneHAN \& Bruce L. Anderson, Considering Cooperation: A Guide for New Cooperative Devel OPMENT (2001), available at http://cooperatives.dyson.cornell.edu/pdf/resources/eb0101.pdf; U.S.D.A., CoOps 101: AN InTroduction to CoOperatives (1997), available at http://www. rurdev.usda.gov/rbs/pub/cir55/cir55rpt.htm.
} 
size ${ }^{93}$ with an executive committee to act as needed between board meetings, ${ }^{94}$ a compensation committee, a governance committee charged, inter alia, with nominating board members, and an audit committee with safeguards to bolster its independence. ${ }^{95}$ As a financial institution, the corporate governance structure of the cooperative would need to foster strong control centers for risk management: a risk committee of board members with supervision over a risk manager; an internal audit function directly accountable to the audit committee; and independent board leadership enabling the board to scrutinize and evaluate management proposals and overall performance. ${ }^{96}$

Cooperative organization implies only one important difference from the corporate governance structure of stock ownership corporations. A cooperative with only marginal exceptions falls within an exemption to the Securities Exchange Act of 1934 and therefore is not subject to SEC proxy rules. ${ }^{97}$ These elaborate restrictions on communication among shareholders, intended to curb predatory and fraudulent activities, have no application within the closed confines of cooperative membership. As a consequence, the cooperative would have a significantly greater capacity for democratic activity at the membership level. Members would, of course, employ proxies in accordance with ordinary agency principles because of the convenience they offer, but, being free of SEC rules and filing requirements, the use of proxies would not encumber dialogue and association among members.

Nevertheless, one continues to find in the literature on GSE reform allusions to the governance weaknesses of cooperatives, expressed as a kind of conventional wisdom. Some commentaries refer to alleged shortcomings of the FHLBank System-we will examine these allega-

93. See The Business Roundtable, Principles of Corporate Governance 14 (2010) ("[S]maller boards often are more cohesive and work more effectively than larger boards.").

94. Am. Law Inst., Principles of Corporate Governance, $\S 3$ A.01 cmt. e (1994).

95. See Carolyn Kay Brancato \& Christian A. Plath, Corporate Governance Handbook 2005: Developments in Best Practices, Compliance, and Legal Standards (2005) (containing an extensive discussion of committee organization and responsibilities, similar to its counterparts issued by The Business Roundtable and the American Law Institute).

96. Michael E. Murphy, Assuring Responsible Risk Management in Banking: The Corporate Governance Dimension, 36 DEL. J. CoRP. L. 121 (2011).

97. Securities Exchange Act of 1934, Pub. L. No. 73-291 $\$ 12 \mathrm{~g}(2)(\mathrm{F}), 48$ Stat. 881, (codified as amended at 15 U.S.C. $\$ 781(\mathrm{~g})(2)(\mathrm{F})(2006)$ ). The SEC proxy rules are found in 17 C.F.R. $\S 240.14$ A (2010). See Michael E. Murphy, Pension Plans and the Prospects of Corporate SelfRegulation, 5 DePaul Bus. \& COM. L.J. 503 (2007) (providing a discussion of the stifling effect that the proxy rules have on the freedom of pension funds to participate in corporate governance.). 
tions in Part VI. The New York Fed staff report concludes with a list of advantages and disadvantages of the cooperative model and also puts governance on the negative side of the ledger. "Historically," it claims, "cooperatives often have weak governance over management, because of their dispersed membership, and lack of market discipline or threat of takeover."98 As empirical support, it cites a study finding that mutual savings banks improve performance after conversion to stock ownership ${ }^{99}$ but fails to mention a second study finding that mutual savings banks hold less risky investments and experience a lower failure rate than stock firms. ${ }^{100}$ Moreover, the governance structure of mutual savings banks, like that of credit unions, is based on a passive membership composed of depositors who have neither the incentive or capacity to monitor management-a far remove from a securitization cooperative owned by large banking institutions with much at stake in its success. The self-corrective capacity of these institutions does not come from their membership, but rather from the guidance of a supportive regulatory infrastructure providing education, forms, audits, technical advice, etc. ${ }^{101}$ Mutual savings banks offer no meaningful analogy whatever.

A securitization cooperative, however, would face certain real governance problems arising from business concentration in the financial services industry. Since the housing crisis, over sixty percent of mortgage originations in 2010 have been produced by five financial institutions. ${ }^{102}$ Though these difficulties would be incurred by any GSE successor, Woodard and Hall cite the risk of domination by a few major banks as a sufficient reason to reject the cooperative option. ${ }^{103}$ Other scholars similarly mention it as an organizational hazard that must be seriously addressed. ${ }^{104}$

To assure representation of smaller banks, the FHLBank System has adopted the questionable approach of limiting the voting rights of

98. Dechario et al., supra note 10 , at $300-01$.

99. Rebel A. Cole \& Hamid Mehran, The Effect of Changes in Ownership Structure on Performance: Evidence from the Thrift Industry, 50 J. FIN. EcoN. 291 (1998).

100. Benjamin C. Esty, Organizational Form and Risk Taking in the Savings and Loan Industry, 44 J. Fin. Econ. 25, 35 (1997); cf. Joan Lamm-Tennant \& Laura T. Starks, Stock Versus Mutual Ownership Structures: The Risk Implications, 66 U. CHI. J. Bus. 29 (1993); Soon Jae Lee et al., Guaranty Funds and Risk-Taking: Evidence from the Insurance Industry, 44 J. FIN. ECON. 3 (1997).

101. See Dougherty v. Carver Fed. Sav. Bank, 112 F.3d 613, 615 (2d Cir. 1997) (explaining the distinction between mutual savings banks and stock savings banks).

102. Dechario et al., supra note 10, at 294; Shear Letter, supra note 36, at 36.

103. See Woodward \& Hall, supra note 33, at 6.

104. Dechario et al., supra note 10 , at 294, 301; Ellen \& Willis, supra note 33 , at 323; Green \& Schnare, supra note 33 , at 20 ; Shear Letter, supra note 36 , at 36. 
individual members and requiring geographical distribution of members on the boards of regional banks. ${ }^{105}$ Such a system of external controls would be impossible to devise for a securitization cooperative of national scope without discouraging participation of key financial institutions. Since participation by individual lenders would vary from negligible levels to a substantial fraction of overall business, voting rights must be proportioned to actual patronage to offer a fair deal to all members.

Alternatively, the interests of minority members can, to some extent, be protected by regulatory measures. The regulatory agency can prohibit discriminatory practices, such as the preferential guarantee fees that Fannie once extended to Countrywide, ${ }^{106}$ and it may be able to devise means of better serving smaller customers. Vickery and Wright describe " "correspondent' relationships" of some smaller banks "whereby they sell some or all of their whole mortgage loans to larger banks, who receive more attractive prices on the GSEs' guarantee and in turn sell the loans they purchased into the TBA market."107 A regulator may require a cooperative to offer these small banks terms that would make such "correspondent" relationships unnecessary.

Familiar corporate governance practices provide other approaches to protect minority interests. The traditional means of assuring minority representation in stock companies is the practice known as cumulative voting, which results in a kind of proportional representation on the board. The alternative method of directorial elections, known as straight voting, allows shareholders to vote separately on each vacancy. A simple majority of fifty-one percent stock interest can then elect all the board. Cumulative voting allows shareholders to multiply their shares by the number of vacancies and cast all their votes for some or only one candidate for election to the board.108 Thus, a shareholder with a $9.4 \%$ stock interest can count on electing one member to a twelve-member board. In the mid-twentieth century, forty percent of American corporations employed cumulative voting. ${ }^{109}$ The statutory charters of national banks ${ }^{110}$ and Fannie Mae ${ }^{111}$ originally required cumulative voting with the apparent intent to pro-

105. 12 U.S.C. $\$ 1427$ (b) (2006). For a discussion of similar restrictions in state laws, see AuTRY \& HALL supra note 67, at 57-58.

106. Morgenson \& RosNer, supra note 20 , at 55 .

107. Vickery \& Wright, supra note 26 , at 14.

108. See Amihai Glazer et al., Cumulative Voting in Corporate Elections: Introducing Strategy into the Equation, 35 S.C. L. REv. 295, 295-96 (1984).

109. Jeffrey N. Gordon, Institutions as Relational Investors: $A$ New Look at Cumulative Voting, 94 Colum. L. Rev. 124, 142-46, 160 (1994). 
mote board accountability to shareholders. But the polarization of board and shareholder relations in the 1980s and 1990s, ${ }^{112}$ stimulated by hostile takeovers and institutional investor activism, has brought a steady decline in the use of cumulative voting and fewer than ten percent of American corporations now practice it. ${ }^{113}$

In his authoritative post-war text on cooperative law, Israel Packel urged cooperatives to consider cumulative voting. ${ }^{114}$ Indeed, it would not be difficult to adapt a system of patronage-based voting to cumulative voting. The voting units of members, measured either by patronage over the past few years or by their capital accounts (if these are managed to reflect patronage in these years) can be multiplied by the board vacancies to be filled in an election. The practice of cumulative voting would enhance the democratic control of the cooperative, particularly in light of the members' freedom to communicate amongst themselves, but in the end it might be seldom used. A coalition of small mortgage lenders might prefer to hold in reserve their cumulative voting rights and instead seek a mutually accommodating consultative relationship with the nominating committee. The right of cumulative voting would enable them to engage in dialogue with the committee from a position of equal strength.

If minority representation could be assured by cumulative voting, the presence of independent directors, without any economic or professional affiliation with members, would assure greater potential importance. ${ }^{115}$ It is true that, unlike stock companies, cooperatives have strong reasons to offer members representation on their boards. The members not only have an incentive to protect their own interests through proper management of the cooperative, but also possess the

110. Banking Act of 1933, Pub. L. No. 73-66, $\S 19,48$ Stat. 162 (1933). The mandatory requirement was repealed in the ironically named Financial Services Regulatory Relief Act of 2006, Pub. L. No. 109-351, $\S 301,120$ Stat. 1966, 1969 (codified at 12 U.S.C. $\S 61$ (2006)).

111. Housing and Urban Development Act of 1968, Pub. L. No. $90-448$, $\$ 802(\mathrm{~h}), 82$ Stat. 476 (1968). The requirement was made optional in the Housing and Community Development Act of 1987, Pub. L. No. 100-242, § 442, 101 Stat. 1815, 1921 (1987) (codified at 42 U.S.C. $\S 5301$ (2006)).

112. For a perceptive discussion of the in-group/out-group polarization among directors and shareholders that evolved in this period, see Rakesh Khurana \& Katarina Pick, The Social Nature of Boards, 70 BROOK. L. REV. 1259, 1279 (2005).

113. See Gordon, supra note 109, at 145-46, 160; Stephen Taub, Qualcomm Seeks End To Staggered Board, CFO MAG., (Jan. 20, 2005), http://www.cfo.com/article.cfm/3576940/c_3576955 ?f $=$ TodayInFinance_Inside.

114. Israel Packel, Law of the Organization and Operation of Cooperatives, 26(c) (4th ed.1970).

115. Cumulative voting would not serve its intended purpose if applied to election for seats reserved for independent directors. It should be limited to member directorships so as to assure minority members a place on the board. 
requisite expertise to do so. ${ }^{116}$ But a limited presence of independent directors may still serve a useful purpose by offering a center dedicated to the interests of the cooperative as a whole, capable of mediating between minority and majority interests. Both the FHLBank System and the Farm Credit System require independent directors in member institutions. ${ }^{117}$ The role and influence of the independent directors however, is a function of their number and their appointments on the board. If independent directors accounted for one-third of the board but provided the board chairman and a swing vote on the nominating committee, they would be in a position to assure a steady attention to the interest of the cooperative as a whole.

In accordance with conventional corporate practice, the cooperative's articles of incorporation might guarantee some key features of corporate governance, ${ }^{118}$ but the board would supply details by drafting the bylaws and charters of individual committees. The regulatory agency should apply caution in injecting itself into this consensual process, but, as in the case of banking institutions, it may still formulate some prescriptive guidance on critical issues, such as reporting obligations and the composition of the auditing committee. The extent of the agency's regulatory power over financial institutions is conventionally measured by its duty to assure safety and soundness in management. ${ }^{119}$

These considerations may suffice to show that critics of the governance structure of the proposed securitization cooperative have mistaken its principal advantage for a weakness. While the devil is in the details of bylaws and regulations, the proposed cooperative offers the potential of a robust and transparent governance structure, protecting the interest of its members and working in parallel with regulatory goals. The cooperative's potential for effective, transparent, and accountable governance is in fact the principal reason for preferring it to the alternative of an industry-owned consortium.

116. See AUTRY \& HALL, supra note 67 , at 54-57.

117. See 12 C.F.R. $\$ \S 611.220,1261.3(a), 1273(a)(2)$, (f) (2010).

118. For example, patronage-based voting rights, cumulative voting, board size, and annual elections

119. See Interagency Standards for Safety and Soundness, 12 C.F.R. pt. 30, app. A; 12 C.F.R. pt. 208, app. D-1; 12 C.F.R. pt. 3364, app. A and 12 C.F.R. pt. 570, app. A. For an argument that banking regulators have been excessively cautious in prescribing basic corporate governance safeguards, see Murphy, supra note 96, at 134, 140, 148. 


\section{Three Further INQuiries}

The matters discussed so far carry a number of implications that should be briefly reviewed. They fall into three categories: fiduciary duty, economies, and too-big-to-fail concerns.

\section{A. Fiduciary Duty}

The desideratum of mortgage lenders and the public lies in a lowcost, low-risk entity offering efficient access to the TBA market. A securitization cooperative would place a fiduciary duty on management to act in furtherance of this business purpose. ${ }^{120}$ The duties would run directly to members, serving their profit-driven interest in access to the capital markets, not to the interest of a third party shareholder entity shielded from competition-the irremediable problem with Fannie and Freddie. ${ }^{121}$ Management's fiduciary duties, it should be added, embrace precisely the same duties of care and fair dealing as those applying to other corporate officers. ${ }^{122}$

There is, however, a strictly political hazard in implementing such a clearly defined fiduciary duty. We have seen that the securitization cooperative would require legislation to authorize a federal charter and establish a reinsurance program. The legislation will almost inevitably face entrenched practices intended to bend the cooperative to a secondary mission of providing low-cost housing. Even in conservatorship, Fannie Mae and Freddie Mac are expected to meet quotas for affordable housing, just as they were before the housing bubble. ${ }^{123}$ The impact of these quotas on the housing crisis has been greatly exaggerated by some partisan critics, but they were still destabilizing to some degree. The Financial Crisis Inquiry Commission found that the

120. Autry \& HALL, supra note 67 , at 65 . In general, the officers and directors of cooperatives owe the same duties of care, loyalty, and fair dealing as other corporate officers and directors. Id. at $62-65$.

121. It may be objected that the problem is in fact remediable. The ordinary solution to absence of competition is to supply that competition. But this facile answer encounters insurmountable difficulties. For example, the GSES' isolation from competition might in theory be avoided by putting the securitization service up for competitive bidding from time to time so that the bidders would be subject to competitive pressure to serve the members' interest, but this approach would run the risk of weakening, or destroying, the TBA market because of (a) the unique and complex nature of the service, (b) the long-term demands of a viable credit guarantee program, and (c) the need to provide a standard and trusted product for world markets. Other ways of introducing competition for the securitization service may be imagined; but since competition requires and engenders product differentiation, competition between different service providers would undermine the standardization that makes the TBA market work.

122. Compare Autry \& HALL, supra note 67, at 62-65, and AM. LAW INST., supra note 94, at $\S \S 4.01(\mathrm{a}), 5.09-5.10$

123. See Fed. Hous. Fin. Agency, FHFA Annual Housing Report (2010) [hereinafter 2010 FHFA REPORT]. 
affordable housing goals "contributed marginally to Fannie and Freddie's participation in those [risky] mortgages." 124 Recent research, moreover, indicates that the quotas have been ineffective in promoting affordable housing for low-income neighborhoods. ${ }^{125}$ Nevertheless, the allure of accomplishing a public purpose without paying for it dies hard.126 Alternatively, this deeply rooted impulse might be met by imposing a fee on securitization with the proceeds going to affordable housing. ${ }^{127}$ Congress imposed such fees on Fannie Mae and Freddie Mac just as the housing bubble burst, and the FHLBank System has long had such a program. ${ }^{128}$ The cause of low-income housing surely deserves attention, but the fees will increase the cost of securitization, which is likely to rise anyway because of the need to adequately fund a credit guarantee program. If raised too high, it would constitute the same questionable scheme of burdening the primary mission of the enterprise by causing it to serve a secondary and conflicting mission.

In any event, the proposed cooperative affords the possibility of a narrowly defined and enforceable fiduciary duty. If the prospects cooperative should be compromised by imposing conflicting mandates or excessive fees, the problem would not lie in the concept of a cooperative per se but in the necessity that it poses of obtaining federal legislation.

124. FCIC, supra note 20, at xxvii; see also Belsky \& RiChARdson, supra note 47, at 109-12.

125. Stuart A. Gabriel \& Stuart S. Rosenthal, Government-Sponsored Enterprises, the Community Reinvestment Act, and Home Ownership in Targeted Underserved Neighborhoods, in Housing Markets and the Economy: Risk, Regulation and Policy (Ed Glaeser \& John Quigley eds., 2009); Xudon An \& Raphael Bostic, GSE Activity, FHA Feedback, and Implications for the Efficacy of the Affordable Housing Goals, 36 J. Real Estate Fin. \& ECON. 207 (2008); Raphael W. Bostic \& Stuart Gabriel, Do the GSEs Matter to Low-Income Housing Market? An Assessment of the Effects of the GSE Loan Purchase Activity on California Housing Outcomes, 59 J. Urban Econ. 458 (2006); Neil Bhutta, GSE Activity and Mortgage Supply in Lower-Income and Minority Neighborhoods: The Effect of the Affordable Housing Goals (Fin. \& Econ. Series, Divs. of Research and Statistics and Monetary Affairs, Fed. Reserve Bd., Working Paper No. 03, 2009), available at http://www.federalreserve.gov/pubs/feds/2009/200903/revision/ 200903pap.pdf.

126. This perennial folly is satirized by the refrain of the traditional Latin American ballad, El Rey: "Con o sin dinero. Haga todo lo que quiero. Yo soy el rey."

127. Hearing, supra note 57, at 152 (statement of James B. Lockhart III).

128. See Mark J. Flannery \& W. Scott Frame, The Federal Home Loan Bank System: The 'Other' Housing GSE, Econ. Rev., Fed. Reserve Bank of Atlanta 34 (2006), available at http://www.frbatlanta.org/filelegacydocs/erq306_frame.pdf; Housing \& Economic Recovery Act of 2008, Pub. L. No. 110-289, $\$ 1402,122$ Stat. 2654, (codified as 12 U.S.C. $\$ 4567$ (a) (2006)). The proceeds go to the National Housing Trust Fund. 


\section{B. Economies}

A 1996 Congressional Budget Office report characterized the GSEs as a "spongy conduit" of the benefit conferred by the implied federal guarantee. For nearly every $\$ 2$ of these benefits, the report contended the enterprises succeeded in "soaking up" nearly $\$ 1 .{ }^{129}$ This point has gained general acceptance. In testimony given in March 2010, Timothy Geithner, the Secretary of the Treasury, observed that "a significant amount of the subsidy [afforded by the implicit federal guarantee] was not passed on to home owners, but instead benefited GSE shareholders, managers, mortgage originators and other stakeholders." 130

This record supports an argument for deep structural reform, but it leaves open the question whether a cooperative would have any peculiar advantages over, say, an industry consortium, in plugging the "spongy conduit." In fact, it would clearly offer two specific savings, though they might be easily outweighed by other factors. The cooperative would not pay dividends on common stock held by third parties, closing one relatively small hole in the conduit. ${ }^{131}$ In addition, a Subchapter $\mathrm{T}$ cooperative would enjoy something close to tax exemption. After deducting dividends paid to members based on patronage, it would have little exposure to tax liability. ${ }^{132}$

Cooperative organization, moreover, would introduce a new context for the payment of executive compensation, resulting in some savings, and quite possibly a more conservative orientation to risk. The GSEs have long been criticized for paying inflated executive compensation decoupled from performance. ${ }^{133}$ The practice, though moderated to a degree, continued during and after the housing crisis. Daniel Mudd, who presided over Fannie Mae in the collapse of 2008, received fourteen million dollars in compensation that year. ${ }^{134}$ In 2009 and

129. Cong. Budget Office, Assessing the Public Costs and Benefits of Fannie Mae and Freddie MaC, at xiv (1996).

130. Housing Finance-What Should the New System Be Able To Do?: Part 1-Government and Stakeholder Perspectives, Hearing before the H. Comm. on Fin. Servs., 111th Cong. 133 (2010) [hereinafter Hearing] (statement of Timothy F. Geithner) available at http://financial services.house.gov/Media/file/hearings/111/Printed\%20Hearings/111-115.pdf.

131. See supra notes $72-74$ and $78-80$ and accompanying text. But it might pay dividends on preferred stock if it chose that means of capitalization.

132. I.R.C. \& 1382(b)-(c).

133. See, e.g., Lucian A. Bebchuk \& Jesse M. Fried, Executive Compensation at Fannie Mae: $A$ Case Study of Perverse Incentives, Nonperformance Pay and Camouflage, 30 J. CORP. L. 807 (2005). Franklin Raines, forced to resign in 2004, received compensation over $\$ 70$ million in value for four years service. Id. at 810 .

134. See Daniel H. Mudd / 2008 Executive Compensation Report, WASH. Post (2008), http:// projects.washingtonpost.com/post200/2008/executive/4998/ (last visited Nov. 25, 2011). 
2010, the CEOs of the two GSEs received a total of seventeen million dollars and the top six executives a total of $\$ 35.4$ million. ${ }^{135}$ This generous compensation during years of heavy losses suggests that the guiding factor was a decision to set compensation at the level of "other publicly held financial institutions or major financial services companies"- a standard prescribed by statute. ${ }^{136}$ The application of this standard to a cooperative would have different points of reference. As service providers to the financial industry, the executives of a securitization cooperative would invite comparison with executives of corporate entities, government agencies, or corporate divisions providing services of similar importance and complexity to other banks. ${ }^{137}$ This comparison would likely lend itself to payment of compensation at a high professional level. Perhaps more significant, the executives of cooperatives would not receive stock compensationthe cooperative has no marketable stock-but rather would be paid in cash. ${ }^{138}$ The siren call of personal payoffs for risky decisions would be muted. The executives would instead face the sober prospect of receiving compensation on the basis of the members' judgment of their performance in rendering a low-cost, low-risk service. This compensation scheme might result in a more cautious approach to risk, suited to a securitization function embracing a very large portion of the secondary mortgage market. ${ }^{139}$

\section{Too-Big-to-Fail Concerns}

The financial crisis has revealed the systemic risks of institutions that are "too big to fail" while increasing the degree of concentration in the financial industry. Despite some financial recovery, some critics contend that this sets the stage for a future crisis. ${ }^{140}$ Philip Swagel, a former assistant Secretary of Treasury, regards this danger as a suffi-

135. Gretchen Morgenson, A Report Faults Mortgage Giants on Leaders' Pay, N.Y. Times, Apr. 1, 2011, at A1.

136. 12 U.S.C. $\S 1723 a(d)(2)$ (Supp. 2008).

137. For example, Ginnie Mae, FHLBank System, district banks in the Farm Credit System, consortiums and clearing houses of the banking industry, and the managers of bank divisions providing specialized services to the industry, such as the tri-party repo market functions of JP Morgan and BNY Mellon. With regard to the tri-party repo function, see FCIC supra note 20, at 283-84.

138. Since 1999, the FHLBanks have been allowed to pay top executives incentive pay based on growth and profitability, but a securitization cooperative, organized under Subchapter $\mathrm{T}$ to provide a low-cost, low-risk service, would not be amenable to such compensation metrics based on growth and profitability. On FHLBank compensation, see Flannery \& Frame, supra note 128 , at 51 .

139. For a discussion of this hypothesis, see $i d$. at 50-51.

140. See Simon Johnson \& James Kwak, 13 Bankers: The Wall Street Takeover and the Next Financial Meltdown (2010). 
cient reason to reject the cooperative option for GSE reform. He writes,

The alternative approach of a private sector cooperative suffers from the problem that having a single such cooperative or even two of them would recreate a system of firms that are too big to fail, just as Fannie and Freddie were (and are) too important to be allowed to fail. ${ }^{141}$

Two contributors to the American Banker state the matter simply: "[T] $\mathrm{T}$ [cooperative] approach would further concentrate the industry among banks that own the cooperatives, which seems 'at cross-purposes' with efforts to address 'too big to fail." 142 The same concern appears in the thoughtful studies of Ellen et al. and Acharya et al., which both allude to risks of insolvency ${ }^{143}$ and bailouts. ${ }^{144}$

The mention of an insolvency risk, however, presupposes that the cooperative would somehow resemble its GSE predecessor. The service-oriented Subchapter $T$ cooperative outlined here would in fact be almost invulnerable to insolvency. As noted earlier, the business of securitization requires short-term credits for cash management and liquidity needs; it must finance the brief gap between purchase and sale of securitized mortgages on the capital markets and maintain the liquidity to handle the irregular flow of large and small transactions. ${ }^{145}$ The Subchapter $\mathrm{T}$ organization gives the cooperative a means of maintaining the capital needed for these limited purposes by withholding a portion of patronage dividends from members and placing these capital credits in a kind of revolving fund. ${ }^{146}$ Thus, once it is successfully launched, the cooperative would have an assured access to a sufficient supply of capital from members to support ongoing operations. In the event of an extreme housing crisis, the members would suffer from a falloff of business, but the cooperative itself would be unlikely to founder over the need to repay its modest shortterm obligations.

The cooperative would undoubtedly rest on a highly concentrated industry, but would it be an element of further concentration? The question takes us to the governance problems previously discussed in Part III. If the cooperative were organized so as to preserve the rights of minority members, it would merely reflect the existing pattern of

141. See Hearing, supra note 35, at 166 (testimony of Philip L. Swagel).

142. Harry Terris \& Marc Hochstein, Eye on GSE Reform, AM. BANKER, Dec. 30, 2010, available at 2010 WLNR 25592070.

143. Ellen \& Willis, supra note 33, at 324.

144. ACHARYA ET AL., supra note 6 , at 158 .

145. See Fed. Oversight Report, supra note 85.

146. See supra notes $79-81$ and accompanying text. 
the industry. It might, of course, be hoped that financial reform of any kind would reduce the persistent hazards of too-big-to-fail financial institutions. The matter opens up large and difficult subjects that lie outside the scope of this article, but the creation of a securitization cooperative would not impede possible lines of progress. Two important directions of reform should at least be mentioned: the secondary market for multi-family housing mortgages and the federal reinsurance program.

The conservator is now charged with gradually unloading the GSEs' $\$ 1.7$ trillion portfolio of mortgage investments, ${ }^{147}$ generally regarded as the element that poses the greatest systemic risk. ${ }^{148}$ At some point in this process, it will be necessary to address the disposition of the GSEs' large multi-family housing portfolio. The manner in which this is done will have immense importance for the fifty million Americans who live in multi-family housing. ${ }^{149}$ The GSEs hold thirty-five percent of multi-family mortgage debt outstanding, and with the contraction of other sources of funding, they provided no less than ninety percent of multi-family mortgage capital in $2010 .{ }^{150}$ The delinquency rates and defaults in multi-family housing mortgages have been far lower than single-family mortgages. ${ }^{151}$

The idiosyncrasies of individual multi-family mortgages and their relatively large size tend to make them unsuitable for securitization. Prior to the conservatorship, the GSEs held sixty-two percent of their multi-family mortgage acquisitions in portfolio; only thirty-eight percent of the mortgages were securitized. ${ }^{152}$ With this large element of portfolio investment, the GSEs' multi-family housing mortgage business does not have a place in the business model of a securitization cooperative as outlined here. In any event, it will make sense to transfer the multi-family program to a distinct entity since separate management will better address its peculiar risks and transactional

147. See ACHARYA ET AL., supra note 6, at 140-141.

148. See Reforming the Regulation of the Government-Sponsored Enterprises: Hearing before S. Comm. on Banking, Hous. and Urban Affairs, 110th Cong. 89 (2008) [hereinafter Hearing] (statement of David G. Nason, Assistant Secretary for Financial Institutions, Department of the Treasury).

149. See generally Boyack, supra note 43, at 1506-08; Ellen et al., supra note 15, at 11-13; Housing Finance: What Should the New System be Able to Do? Hearing before the H. Comm. on Fin. Servs., 111th Cong. 54 (2010) [hereinafter Hearing] (statement of Robert E. Dewitt, President, CEO, and Vice Chairman, GID Investment Advisers LLC).

150. See Hearing, supra note 149, at 1, 3 (testimony of Robert E. Dewitt).

151. See Hearing, supra note 2, at 57 (statement of Edward J. DeMarco).

152. National Multi Housing Council, NMHC Research Notes: The GSEs' Role in Multifamily Finance (2009), available at http://www.nmhc.org/Content/ServeContent.cfm? ContentItemID $=5039$. 
characteristics. ${ }^{153}$ The most plausible solution is perhaps to transfer it to a government agency, while entrusting the securitization to Ginnie Mae. The effect of splitting off the multi-family business to another enterprise or agency would be to reduce incrementally the scope of the activities carried out by the proposed securitization cooperative.

The most justified of the too-big-to-fail concerns revolve around the credit guarantee program, with an attendant federal reinsurance system, that is needed to securitize mortgages on the TBA market. The vital task of managing public exposure in this reinsurance program will pertain to the regulatory agency overseeing the GSE successors. The Federal Housing Finance Agency has already acted to restrict the kinds mortgages eligible for a credit guarantee by raising underwriting standards ${ }^{154}$ and lowering the cap on the size of eligible mortgages (after temporarily raising it). ${ }^{155}$ In the event of a housing revival, the agency might do well to eliminate guarantees to non-occupant housing (second homes and investor-owned homes), ${ }^{156}$ and to scrutinize the sort of cash-out withdrawals of equity that fed the housing bubble. ${ }^{157}$ The adoption of a securitization cooperative would not affect these policy decisions. The mission of the cooperative would be merely to carry out the securitization of those mortgages that the regulatory agency deems eligible for federal reinsurance.

These modest suggestions avoid an obvious, but ultimately unsound solution: to break the GSEs into several cooperatives or other entities. The effective securitization of home mortgages strongly militates in

153. See Hearing, supra note 149 , at 8 (testimony of Robert E. Dewitt); Ellen \& Willis, supra note 33 , at $318-19$.

154. See Hearing, supra note 2, at 49-50 (statement of Edward J. DeMarco).

155. David Streitfeld, Federal Retreat on Bigger Loans Rattles Housing, N.Y. Times, May 11, 2011, at A1, available at http://www.nytimes.com/2011/05/11/business/11housing.html?page wanted $=$ all.

156. The case for eliminating mortgage guarantees on non-occupant housing rests on the volatility of this market and the lesser social importance of ownership of homes that do not serve as a primary residence. See Joseph R. Mason \& Joshua Rosner, How Resilient are Mortgage Backed Securities to Collateralized Debt Obligation Market Disruptions?, 11, fig. 5A (forthcoming), available at http://citeseerx.ist.psu.edu/viewdoc/summary?doi=10.1.1.168.1953; Belsky \& Richardson, supra note 47 , at 47 , figs.3-1, 3-8.

157. Cash-out refinancing stimulated the housing bubble and often provided no benefits for housing, but, in normal times, mortgage refinancing supports a broad sector of the economy and represents a legitimate way of drawing on family savings. The question of how these mortgages should qualify for securitization thus involves a balancing of considerations that may change with the housing cycle. See Belsky \& Richardson, supra note 47, at 35-38, 47, fig.3-3; Belsky \& Prakken, supra note 62, at 1-33; Alan Greenspan, Remarks at the Annual Convention of the Independent Community Bankers of America, at 1-2, (Mar. 4, 2003) available at www.federalreserve.gov/boarddocs/speeches/2003/20030304/default.htm. See also John M. Quigley, Federal Credit and Insurance Programs: Housing, Fed. Reserve Bank of St. Louis 25 (July-Aug. 2006) (arguing for limiting GSE mortgage activity to first-time home buyers). 
favor of a limited number of issuers of mortgage-backed bonds, underwritten by a single government reinsurance agency. A larger number of issuers would strain the process of standardization and might not reduce credit risks since the financial products of all the issuers must be highly correlated to meet the demands of capital markets. The issuers would probably stand or fall together, as did Fannie and Freddie. Hence, it is probably best to maintain the existing structure of the TBA market with three issuers, Ginnie Mae, and two successors to Fannie and Freddie.

\section{Precedents}

\section{A. Federal Home Loan Bank System}

Any discussion of the cooperative option for a GSE successor leads inevitably to controversy over the record of the FHLBank System, a huge cooperative institution providing a vital source of liquidity to the banking system. In written testimony before a House committee, Bruce Morrison, former Chairman of the Federal Housing Finance Board, cites the long history of the FHLBank system as favoring the cooperative ownership of a GSE successor. "This kind of cooperative capital structure," he writes, "has worked for the Federal Home Loan Banks as providers of low risk, low return products for the past 85 years." 158 Other commentators have pointed to risky investments of some Federal Home Loan Banks and their precarious financial condition in 2008 and 2009. ${ }^{159}$ Their common assumption is that these signs of weakness reveal the presence of moral hazard and a potential for self-dealing inherent in its cooperative structure. This assumptionand Morrison's positive assessment-calls for closer consideration.

The FHLBank System consists of twelve regional banks and a central agency, the Office of Finance. It was established in 1932 to provide a source of home mortgage funding for financially distressed savings banks that became both shareholders in the twelve regional banks and beneficiaries of the regional banks' lending activities. ${ }^{160}$ All savings banks were required to join a regional bank by purchasing a certain quantity of capital stock and to invest a percentage of loans they received in further stock purchases. They could redeem this ad-

158. See Hearing, supra note 10, at 161 (statement of Bruce Morrison); see Dechario et al., supra note 10, at 293-298; WEISS, supra note 35, at 15 (indicating other generally favorable comparisons of the cooperative option with the FHLBank System).

159. See Reiss, supra note 33, at 952; Stanton, supra note 33, at 243-44; Shear Letter, supra note 36, at 6, 33; Green \& Schnare, supra note 33, at 43-44.

160. Federal Home Loan Bank Act, Pub. L. No. 72-304, 47 Stat. 725 (1932) (codified at 12 U.S.C. $\$ 1421$ (2006)). 
ditional stock at par value with six months notice. Since the capital stock conferred voting rights, the members collectively gained power to elect their chosen candidates to the board of directors. The regional banks engaged in a single, conservative form of lending: they extended loans, known as advances, that were secured by collateral exceeding the value of the loans as well as by a lien on member's capital stock. Funding for the loans was provided by bonds issued by the Office of Finance for which all regional banks were jointly and severally liable. ${ }^{161} \mathrm{~A}$ federal agency known as the Federal Home Loan Bank Board supervised banking operations within the FHLBank System. ${ }^{162}$

For fifty years, the regional banks served as "an established, stable source of continual funding to support the thrift industry in making mortgage loans." 163 To serve the expanding secondary mortgage market, Congress created a separate corporation, dubbed Freddie Mac, with equity shares held by the twelve regional banks in the FHLBank System. ${ }^{164}$ The banks themselves continued with the business of secured lending to member savings and loans associations. This prosperous trajectory was tested by the savings and loan crisis of the 1980s, but the FHLBank System survived a temporary decline in lending without a credit loss ${ }^{165}$ and provided important source of funding for the bailout of the savings and loan industry. ${ }^{166}$

The crisis led to legislation that radically transformed the FHLBank System in the next twenty years. In 1989, the Financial Institutions Reform, Recovery, and Enforcement Act (FIRREA) opened membership in regional banks to most commercial banks, credit unions, and insurance companies, which could join or leave the system on a

161. U.S. Gov't Accountability Office, GAO-05-489T, Federal Home Loan Bank System, An Overview of Changes and Current Issues Affecting the System 5-6, 9 (2005) [hereinafter GAO]; Oversight of the Federal Home Loan Bank System: Hearing before the Subcomm. on Fin. Insts. of the S. Comm. on Banking, Hous., and Urban Affairs, 108th Cong. 120-21 (2003) [hereinafter Hearing] (article of Sheila C. Bair, Is the Federal Home Loan Bank System Forsaking Its Roots? at 120-21); Flannery \& Frame, supra note 128, at 33, 38.

162. Federal Home Loan Bank Act, Pub. L. No. 72-304, $\S \S 17-20,47$ Stat. 725 (1932) (codified at 12 U.S.C. $\$ 1421(2006)$ ).

163. See Hearing, supra note 161, at 121 (article of Sheila C. Bair).

164. Emergency Home Finance Act of 1970, Pub. L. No. 351, $\S \S 302-10,84$ Stat. 450 (1970) (codified as amended in scattered sections of 12 U.S.C.).

165. See Hearing, supra note 161, at 122 (article of Sheila C. Bair).

166. The FHLBanks contributed $\$ 2.5$ billion in capital to the Resolution Funding Corporation and assumed a $\$ 300$ million annual obligation to fund 30-year bailout bonds (later adjusted to twenty percent of net income). See GAO, supra note 161, at 7; Jonathan A. Scott \& Scott E. Hein, The Federal Home Loan Bank System: A Government Sponsored Enterprise that Avoided Conservatorship, 21 J. APPLIEd Fin. 46 (2011); 12 U.S.C. \$§ 1441(d) \& 1441b(f) (2006). 
voluntary basis, ${ }^{167}$ and provided that the shares of Freddie were to be freely transferrable, leading it to become an independent publicly owned stock corporation. ${ }^{168}$ In 1999, the Gramm-Leach-Bliley Act (GLB Act) made the participation of savings banks voluntary. ${ }^{169}$ To stabilize the capital base, the GLB Act authorized regional banks to issue a Class B stock that could be redeemed with five-years' notice unless it would then jeopardize capital requirements. ${ }^{170}$ The regional banks thereafter confined nearly all stock issues to this Class B stock. ${ }^{171}$ The GLB Act also imposed stricter capitalization requirements that generally required an effective four percent equity capitalto-asset leverage ratio. ${ }^{172} \mathrm{~A}$ newly constituted regulatory agency, the Federal Housing Finance Board, maintained a safety and soundness review of the entire system. ${ }^{173}$

In the twenty years after the savings and loan crisis, the FHLBank System experienced extraordinary growth both in membership and financial resources. ${ }^{174}$ The number of member banks increased more than threefold to about eight thousand. ${ }^{175}$ Commercial banks came to represent over seventy percent of the membership, ${ }^{176}$ and the largest banks acquired an increasingly important share of the business. ${ }^{177}$ For the decade between 1993 and 2003, the traditional lending activity of the banks rose at a compounded annual rate of no less than twentythree percent, ${ }^{178}$ and, in addition, the regional banks made significant portfolio investments in marketable securities and whole mortgages. Total assets rose from 175 billion in 1989 to a trillion in 2006. ${ }^{179}$ Per-

167. Financial Institutions Reform, Recovery \& Enforcement Act of 1989 (FIRREA), Pub. L. No. 101-73, § 704, 103 Stat. 183, 415-416, (1989) (codified as amended in scattered sections of 12 U.S.C.).

168. FIRREA $\$ 731(\mathrm{~d})(2), 103$ Stat. $183,432$.

169. Gramm-Leach-Bliley Act (GLBA), Pub. L. No. 106-102, §§ 602 and 608(d), 113 Stat. $1338,1450,1461$ (1999).

170. GLBA \& 608(a)(4), (f).

171. Flannery \& Frame, supra note 128 , at 42.

172. GLBA $\S 608$ (b) \& (c); 12 C.F.R. $\$ 932.2$.

173. Financial Institutions Reform, Recovery \& Enforcement Act of 1989 (FIRREA), Pub. L. No. 101-73, $\$ 702,103$ Stat. 183, 413 (1989) (codified as amended in scattered sections of 12 U.S.C.) (amended by Federal Housing Enterprises Financial Safety \& Soundness Act of 1992, Pub. L. No. 102-50, $\S 1391,106$ Stat. 1341, (2009) (codified as amended in scattered sections of 12 U.S.C.)).

174. See GAO, supra note 161 , at $12-13$.

175. See Hearing, supra note 161, at 123 (article of Sheila C. Bair).

176. See GAO, supra note 161 , at 3 .

177. By 2006, the five largest members of the regional banks provided between twenty-nine percent and seventy-four percent of the FHLBanks' capital accounts in regional banks. See Flannery \& Frame, supra note 128 , at 43.

178. Scott \& Hein, supra note 166 , at 43.

179. 2010 FHFA REPORT, supra note 123, at 55; Flannery \& Frame, supra note 128, at 34. 
haps abetting this expansion, when the GLB Act loosened controls on executive compensation, the regional banks roughly doubled incentive compensation schemes for top executives based on the banks' earnings and growth. ${ }^{180}$

From the earliest years, the FHLBank System enjoyed special privileges, including exemption from securities regulation, which evolved and expanded over time to give its securities the appearance of an implied federal guarantee. ${ }^{181}$ The consolidated obligation bonds issued by the Office of Finance traded at an interest rate very close to comparable U.S. Treasury bonds. ${ }^{182}$ This access to cheap funding offered regional banks a very profitable opportunity of "borrowing funds in the capital markets at below market rates and investing them in securities at market rates." 183 The portfolio investments, exploiting this kind of arbitrage, rose from about ten percent of assets in the 1980s to levels ranging between thirty and fifty percent of total assets in the 1990 s. $^{184}$ Besides short-term obligations serving liquidity needs, the banks invested primarily in mortgage-backed securities issued by Fannie Mae and Freddie Mac, ${ }^{185}$ but during the housing bubble, they also began investing in private-label mortgage-backed securities, which amounted to about five percent of total assets by the end of 2007. ${ }^{186}$

By 2000 , every regional bank had launched a mortgage purchase program that placed it in direct competition with Fannie and Freddie. Under a program developed by the Chicago Bank, the member banks sold mortgage loans to the regional banks but retained most of the credit risk under a complicated formula. The regional banks made monthly payments to the member for assuming this credit risk and handled the interest and prepayment risk with derivatives or other means. A smaller number of regional banks, including the Seattle Bank, maintained a similar mortgage purchase program with its own eligibility rules and formula for sharing the credit risk. ${ }^{187}$ The mort-

180. 2010 FHFA REPORT, supra note 123 , at 50-51.

181. See id. at 36 (listing and describing of these privileges).

182. See id; Scott \& Hein, supra note 166, at 46.

183. Hearing of Subcomm. on Capital Mkts., Sec., and Gov't-Sponsored Enters., of the H. Comm. on Banking and Fin. Servs., 105th Cong. 74 (1998) (statement of Richard S. Carnell, Assistant Secretary of Treasury).

184. See Hearing, supra note 161, at 124 (article of Sheila C. Bair).

185. See GAO, supra note 161 , at 14 .

186. Cong. Budget Office, Fannie Mae, Freddie Mac, and the Federal Role in the Secondary Mortoage Market, 57 (2010) [hereinafter CBO]; Scott \& Hein, supra note 166, at 52 fig.1.

187. W. Scott Frame, Federal Home Loan Bank Purchases: Implications for Mortgage Mar. kets, 88 Econ. Rev. Fed. Reserve Bank of Atlanta, no. 3, 2003 at 19-23. 
gage purchase programs grew explosively for a few years and accounted for most of the portfolio investments of the FHLBank System by $2002 .{ }^{188}$ At this point, a drive led by the largest bank members toward a program of actual securitization in capital markets appeared to gain momentum. The Chicago Bank edged toward such a securitization program by selling mortgage loans to members, who in turn arranged to market the mortgages through their own private label mortgage-backed securities. ${ }^{189}$ But this trend was deflected in 2004 when the Federal Home Loan Board brought enforcement actions against the Chicago and Seattle Banks challenging practices relating to the mortgage purchase programs. ${ }^{190}$ The mortgage purchase programs peaked in 2003 before Fannie and Freddie made their last fatal plunge into these risky waters. ${ }^{191}$

At the threshold of the housing crisis, the FHLBank System had become a very large, highly leveraged, and complex wholesale banking institution with a broad range of products, investments, and services extending well beyond the limits of this brief description. It had lost its close connection with the home mortgage industry. While mortgages were still the principal form of collateral for secured loans, the loans themselves were available for general banking purposes. ${ }^{192}$ Instead, the FHLBank System had assumed a new raison d'être as a source of liquidity for the entire banking industry. It was in fact the largest lender to domestic depository institutions. ${ }^{193}$

This new role proved its importance to the country's financial system when ratings agencies began to downgrade private-label mortgage-backed securities in July 2007. In the next twelve months, the FHLBank System increased its secured lending to members by $\$ 274$ billion, bringing total advances to $\$ 914$ billion by June $30,2008.194$ Until March 2008, it exceeded the Federal Reserve as a counter-cyclical source of liquidity, ${ }^{195}$ but as the financial crisis deepened, banks

188. See id. at 124-125.

189. See Hearing, supra note 161 , at 135-36 (article of Sheila C. Bair).

190. See GAO, supra note 161 , at 17.

191. See CBO, supra note 186 , at 56 . On the division of opinion between large member banks advocating entering the secondary mortgage markets and the broader membership, see GAO, supra note 161, at 2, 18; Hearing, supra note 161, at 134, 136, 141 (article of Sheila C. Bair).

192. See CBO, supra note 186, at 56; W. Scott Frame, Diana Hancock \& Wayne Passmore, Federal Home Loan Bank Advances and Commercial Bank Portfolio Composition, at 29 (Fed. Reserve Bd., Washington D.C., Staff Working Paper No. 31, 2007).

193. Adam B. Ashcraft et al., The Federal Home Loan Bank System: The Lender of Next-toLast Resort, NY Fed. Reserve Bank 5 (Staff Report No. 357, 2008).

194. See id. at 3,10-12, 18-21.

195. See id. at 4, 41 fig.3. 
turned increasingly to the Federal Reserve System and U.S. Treasury for assistance, and demand for FHLBank advances declined.

In 2008 and 2009, most (but not all) regional banks reported serious losses from their ventures into the secondary mortgage market. The mortgage purchase programs fared relatively well. According to the CBO, "At the end of 2009, less than 2.4 percent of the banks' mortgage holdings were seriously delinquent (90 days past due or in foreclosure), compared with 4.8 percent for Fannie Mae and Freddie Mac and 9.7 percent for the industry as a whole." 196 But the quality of the banks' investments in private-label mortgage-backed securities declined sharply, requiring charges of $\$ 2$ billion in 2008 and $\$ 11.4$ billion in 2009.197 For two years, the financial press circulated reports of the FHLBanks' precarious financial condition. ${ }^{198}$ Two regional banks, Chicago and Seattle, suspended redemption of capital stock and payment of dividends on order of the Federal Housing Finance Agency (the successor to the Federal Housing Finance Board). ${ }^{199}$ But by 2011 the System appeared to be approaching a point of stability. Although advances were down, consolidated income for 2010 stabilized at a slightly higher level than the preceding year, and charges attributable to private-label mortgage-backed securities decreased. ${ }^{200}$ The Obama administration now calls for preserving a downsized FHLBank System with fewer risky portfolio investments and closer ties to the home mortgage industry. ${ }^{201}$

\section{B. Significance of FHLBanks' Cooperative Structure}

This survey of the FHLBank System should serve at least to show that it is a unique and exotic creation in the world of cooperatives,

196. See CBO, supra note 186 , at 57.

197. See Fed. Hous. Fin. Agency, 2009 Report to Congress 66 (2009) [hereinafter 2009 FHFA REPORT].

198. See, e.g., James R. Hagerty, Home-Loan Banks Struggle to Maintain Capital, WALL St. J., Jan. 21, 2009, at A6, available at http://online.wsj.com/article/SB123249600058500249.html\#print Mode; Joe Rauch, FHLB of Atlanta Sees Trouble Too, Atlanta Bus. Chron. (Nov. 21, 2008), available at http://www.bizjournals.com/atlanta/stories/2008/11/24/story5.html?b=1227502800\% 5E1737034.

199. See Hearing, supra note 2, at 54. (statement of Edward J. DeMarco).

200. 2010 FHFA REPORT, supra note 123, at 48-49.

201. See Reforming Am., supra note 8, at 14-15; Hearing, supra note 2, at 11 (statement of Edward J. DeMarco) ("FHFA is looking for the Home Loan Banks to return to more traditional operations and activities, with a focus on advances to member institutions, and a gradual reduction in investment portfolios which are not needed to support core business activities and safety and soundness."); Donna Borak, Will FHFA Membership Plan Kill the FHLBank System?, NAT'L Mortg. News, Apr. 18, 2011, at 12, available at http://www.nationalmortgagenews.com/ dailybriefing/2010_322/will-fhfa-membership-plan-1024261-1.html. 
radically different from cooperative banking institutions, ${ }^{202}$ Subchapter $T$ cooperatives, and the securitization cooperative outlined earlier. Incorporating a fundamental conflict of interest, it exists to extend credit (or liquidity) to the members who control it. In other words, it is a creditor controlled by its debtors, who have more reason to consider their own interests than that of the creditor. This inherent source of instability is exacerbated by two risk-shifting features. First, it allows regional banks to shift risk arising from their activities to other regional banks by funding lending through bonds for which all regional banks are jointly and severally liable. Second, the System as a whole shifts the residual risk of lending to the public through the implicit federal guarantee of its bonds.

Analyzed in terms of conflict of interest or moral hazard, the FHLBank System should have failed, but it has instead enjoyed a long life and demonstrated repeated resilience. The success of the System for the first sixty years of its existence can be easily explained by its conservative strategy of secured lending and a captive membership of savings banks, but its resilience in the past twenty years represents more of an enigma. Much of the credit for its survival can surely be attributed to the continued importance of the conservative secured lending operations that have traditionally served the interests both of the System and the members. Some credit is probably also due to a relatively effective regulator, the Federal Home Loan Bank Board, which conducted periodic examination, kept capital levels above those of the other GSEs, and intervened to block unsound practices at the Chicago and Seattle Banks. ${ }^{203}$

But did the cooperative structure of the FHLBank System also play a role in its survival? The clearest connection lies in its method of capitalization. The regional banks maintain required capital reserves by means that resemble those of other cooperatives: they require members to invest two to six percent of their loans in dividend-bearing capital stock, redeemable on five-years' notice provided that the banks' capitalization remains adequate. ${ }^{204}$ This capital stock consti-

202. See generally supra notes $102-04$ and accompanying text. Credit unions and mutual banks have a passive membership of depositors that exerts little, if any, influence on governance. Moreover, the equity owners (in their capacity as depositors) are also liability holders-a simple structure that precludes risk shifting to third parties. See Flannery \& Frame, supra note 128, at 48. More fundamentally, credit unions and mutual banks serve primarily as vehicles for members' savings, while the FHLBanks exist solely to extend credit to members.

203. See 12 U.S.C. $\$ 1440$ (2006) (annual examinations); Rules of Practice and Procedure in Hearings on Record, 12 C.F.R. $\S 1209.1$ (2010) (enforcement); Federal Home Loan Bank Risk Management and Capital Standards, 12 C.F.R. $\$ 930$ (2010).

204. See Ashcraft et al., supra note 193, at 11. 
tutes a kind of revolving fund like that of other cooperatives, though replenished by stock purchases rather than by withholdings of patronage dividends. Most importantly, it increases with the amount of business with the members so as to maintain an adequate level during periods of expansion. Throughout the financial crisis, the capital reserves remained above the required four percent of capital, with only two quarterly exceptions at the Seattle Bank, and stood at $5.92 \%$ of assets at the end of 2009.205

A more important, though somewhat ambiguous factor is the FHLBank System's orientation to risk. While the other GSEs, like the commercial banks, abandoned caution to chase the housing bubble, the regional banks in the FHLBank System were deeply divided on the merits of entering into the secondary mortgage market. The result was a mixed record on risk management that proved to be good enough to insure the System's survival. The underwriting of secured loans, which adjusted collateral requirements to risk, avoided a single credit loss. ${ }^{206}$ According to the Federal Home Finance Agency, the mortgage purchase program assembled a portfolio of "fixed-rate amortizing loans, well-seasoned, written to traditional underwriting standards," which have "high credit scores and relatively low loan-tovalue ratios, and are credit enhanced either by the member who sold the loan to the FHLBank or by supplemental mortgage insurance."207 The banks pulled back from ambitious plans, advocated by the Chicago Bank president, to engage Fannie and Freddie in active competition. ${ }^{208}$ Today, the banks serve as agents for member banks in submitting bundles of mortgage loans to the two GSEs. ${ }^{209}$

A conservative risk management orientation was most evident among the regional banks with a large base of small member banks. The Des Moines Bank, for example, invested only $\$ 69$ million in private-label mortgage-backed securities. ${ }^{210}$ These regional banks also tended more than others to eschew high executive salaries and generous incentive pay rewarding expansion into new areas of invest-

205. 2009 FHFA REPORT, supra note 197 , at 64 .

206. See Scott \& Hein, supra note 166, at 49-50; 2010 FHFA REPORT, supra note 123, at 59. 207. 2009 FHFA REPORT, supra note 197 , at 66.

208. See Oversight of Government-Sponsored Enterprises: The Risks and Benefits of GSEs to Consumers: Hearing before the Fin. Mgmt., the Budget, and Int'l Sec., Subcomm. for the S. Comm. on Gov't Affairs, 108th Cong. 43 (2003) (statement of Alex J. Pollock, President and CEO, Federal Home Loan Bank).

209. CBO, supra note 186 , at 56. Five of twelve regional banks no longer purchase whole mortgages. Id. at 57.

210. Compare Ashcraft et al., supra note 193, at 33 tbl.1 (members) and 2009 FHFA Report, supra note 197, at 67 fig.36 (private-label mortgage-backed securities). 
ment. ${ }^{211}$ The banks cooperative mission of rendering a service to members, albeit a credit service, may well underlie the persistence of such conservative policies in important sectors of the System.

The FHLBank System's cooperative structure, in short, appears to have been a source of strength that helps explain its survival through the housing crisis, despite the instability built into its statutory structure. The System continues to invite reform but seems likely to remain an important source of liquidity and a counter-cyclical factor in the banking system.

\section{Farm Credit System}

Several critics suggest that bailout of the Farm Credit System in the 1980s provides additional evidence of the weakness of the cooperative form of organization. ${ }^{212}$ Stanton uses the example of the Farm Credit System to support a categorical generalization about cooperatives. He writes,

The cooperative governance structure fails to add quality to the GSE model .... [T] The cooperative GSE has an incentive to serve the cooperative owners who use its services. That incentive led the Farm Credit System to provide credit to its cooperative borrowers below the GSE's own cost of funds. ${ }^{213}$

The Farm Credit system, like the FHLBank System, is in fact a rare species of cooperative chartered to extend credit to its members. As noted earlier, the activity presents a moral hazard not present in other cooperatives. A cooperative offering a service, such as marketing, purchasing, or securitization, benefits its members by keeping costs at a minimum, but a cooperative extending credit to its members may undermine its own stability by underpricing its loans. The Farm Credit System presents the unique feature of a double-layered credit cooperative, which might seem to compound this element of instability. It consists of five wholesale district banks that secure funding from a common agent, the Federal Farm Credit Banks Funding Corporation, and provide loan funds to eighty-four retail lending associations. The retail associations are cooperatively owned and in turn own the district banks. ${ }^{214}$ Viewed in terms of moral hazard, it would seem to be a house of cards. Indeed, like many other financial institutions,

211. Fed. Home Loan Banks, 2007 Combined Financial Report 240 (2007). Even at the Chicago Bank, the incentive pay did not exceed the bank president's salary in 2007.

212. Reiss, supra note 33, at 952-54; Stanton, supra note 33, at 242-43; Shear Letter, supra note 36 , at 6 .

213. Stanton, supra note 33 , at $242-43$.

214. See Econ. Research Serv./U.S.D.A., Credit in Rural America 11-12 (1997); Farm Credit Admin., 2010 Annual Report on the Farm Credit System 9-1, 14-15, 19 (2011). 
the System did miscalculate interest rate risks in the 1980s, requiring a federal bailout, but it has survived for almost one hundred years and now serves as an important feature of the agricultural economy.

A product of the progressive movement, the Farm Credit System was established in 1916 in essentially its present form (i.e. as a system of district banks and cooperatively organized loan associations) and underwent a detailed reorganization more than fifty years later in the Farm Credit Act of $1971 . .^{215}$ A decline in interest rates in the 1980s combined with economic distress in the farm economy caught the System holding long-term high interest debt and an excessive number of bad loans. ${ }^{216}$ In 1987, it received a bailout of $\$ 1.26$ billion. ${ }^{217}$ To ward against future defaults, Congress established a self-insurance system ${ }^{218}$ administered by the Farm Credit System Insurance Corporation, which now maintains an insurance fund of $\$ 3.2$ billion. ${ }^{219}$ Equally important, the System is today regulated by the Farm Credit Administration (FCA) in much the same manner as banking institutions within the jurisdiction of the Federal Reserve and Office of the Controller of the Currency. The FCA conducts periodic audits, gives ratings to individual banks and associations, and possesses an array of remedies to correct deficiencies. ${ }^{220}$ In addition, the FCA oversees a unique system of selecting the boards of member institutions. Shareholders in member banks and associations elect representatives to serve on nominating committees that are entirely independent of the existing boards.

For further description of Farm Credit System institutions, see http://www.fca.gov/ FCS-Institutions.htm. See 12 U.S.C. \$§ 2001-2279cc (2006).

215. Federal Farm Loan Act of 1916, Pub. L. No. 64-158, 39 Stat. 360; Farm Credit Act of 1971, Pub. L. No. 92-181, 85 Stat. 583.

216. Econ. Research Serv./U.S.D.A., supra note 214, at 12 n.9; Thomas H. Stanton, A State of Risk: Will Government-Sponsored Enterprises Be the Next Financial Crisis? 77-78, 94-95, 124-25, 141-43, 159-61 (1991).

217. The bailout agency was authorized to issue $\$ 4$ billion in bonds but actually issued only $\$ 1.26$ billion to fund a bailout. See David Nickerson \& Ronnie Philip, The Federal Home Loan Bank System and the Farm Credit System: Historic Parallels \& Implications for Systemic Risk, in Too Big to Fail, Policies and Practices in Government Bailouts 107, 127 (Benton E. Gup, ed., 2004); David Reiss, The Federal Government's Implied Guarantee of Fannie Mae \&

Freddie Mac's Obligation: Uncle Sam Will Pick up the Tab, 42 GA. L. Rev. 1019, 1075-76 (2008).

218. Agricultural Credit Act of 1987, Pub. L. No. 92-181, 85 Stat. 583, (codified at 12 U.S.C. $\S 2011$ (2006)). For an evaluation of these reforms, see Hearing before the Subcomm. on Conservation, Credit, and Rural Dev., H. Comm. on Agric. (1991) (statement of Robert D. Reischauer, Director Congressional Budget Office), available at www.cbo.gov/doc.cfm?index=7930.

219. See www.fcsic.gov (1st Quarter Fund Graph).

220. On examinations and enforcement remedies, see FARM Credit Admin., The DirecTOR's Role: FARM CRedit System Institutions 7-9, 31-35, available at http://www.fca.gov/ Download/directors_role_0406_with_links.pdf. 
The committees nominate two candidates for each board vacancy. 221 The member institutions must reserve two positions on their boards for outside directors, at least one of whom must be a financial expert who serves on the audit committee.222

At the end of 2009, the Farm Credit System held $43.4 \%$ of debt secured by farm real estate and $36 \%$ of non-real estate farm debt, 223 with its lending concentrated among larger, full-time farmers who form the heart of the agricultural economy. ${ }^{224}$ During 2010, its portfolio of loans grew $6.4 \%$ and stood at $\$ 175$ billion by year-end. ${ }^{225}$ The System suffered relatively little stress in the financial crisis. ${ }^{226}$ Only two associations failed to meet capital requirements in 2010; and net earnings, return on capital, and average assets all increased substantially.227

The Farm Credit System today appears to have compensated for the inherent instability of its statutory mission with an effective regulatory regime and governance structure that prevents destructive self-seeking of individual members. Confined to its statutory mission to assist farmer members, the Farm Credit System has lacked the alternative of diversification but appears to have adapted in its own way to the hazard of undue pressure from credit-needy members. Today, it offers evidence of the potential strength of cooperative organization.

\section{CONCLUSION}

While this Article has devoted much space to dispelling misconceptions and mistaken inferences regarding cooperative organizations, certain affirmative points have also emerged. First, the conventional Subchapter $\mathrm{T}$ form of cooperative organization offers a clear alternative for a securitization cooperative. This conclusion does not preclude the possibility of designing a regulated industry consortium or a hybrid entity with some cooperative features. Such an entity might also be dedicated to the limited and specified mission of providing mortgage originators with efficient access to the TBA market, but it is unclear how it would offer the accountability and transparency inher-

221. Id. at 60-61; Bank \& Association Nominating Committees, 12 C.F.R. $§ 611.325(\mathrm{a})$, (d) (2010).

222. 12 C.F.R. $\$ \$ 611.210(a)(2), 611.220,620.30$ (a) (2010). Exceptions may be made for very small associations.

223. FARM CRedit Admin., supra note 214, at 22.

224. Charles B. Dodson \& Steven R. Koenig, Competition in Farm Credit Markets, Identifying Market Segments Served by Farm Credit System, 64 Agric. Fin. Rev. 167 (2004).

225. FARM Credit Admin, supra note 214, at 12, 15.

226. Id. at 2 .

227. Id. at $12,14,18$. 
ent in the conventional cooperative form. The advocates of a utility model or a cooperative-utility model have the burden of explaining how such an exotic structure could offer advantages comparable to those of the familiar Subchapter $T$ cooperative. Secondly, a Subchapter $T$ cooperative offers an effective means of maintaining the capital needed to maintain the service of securitization in the TBA secondary mortgage market. Thirdly, despite widely held misconceptions about cooperatives, a securitization cooperative may in fact be expected to offer a strong system of corporate governance. The chief attraction of a Subchapter T cooperative is its potential for providing an efficient and accountable means of providing the service of securitization for the TBA secondary mortgage market. 
